\title{
Osmanlı İmparatorluğu ile Almanya Devleti Arasındaki Ticaretle İlgili Gümrük Tarife Defteri (1862)*
}

\section{The Customs Tariff Records About the Trade Between the Ottoman Empire and Germany (1862)}

\author{
Murat FIDAN**
}

Öz

Osmanlı Devleti Almanya ile imzaladığı 1840 ticaret anlaşmasılyla birlikte uygulamaya koyduğu gümrük tarifesini değiştirmek istemiştir. Bu değişimde iki önemli etken dikkat çekmektedir. Birinci etken ürün fiyatlarındaki artı̧̧ ile alınan gümrük vergisinin azalması olacaktır. İkinci etken ise dünya konjonktürü̈ndeki gelişmelere bağlı olarak kadîm iktisadî anlayışını değiştirme girişimleri olacaktır. Osmanlı Devleti, Almanya ile gümrük tarifesini 20 Mart 1862 ticaret anlaşması sonrası yenilemiştir. Tarife Osmanlı Türkşesi olarak hazırlanmıştır. Latin alfabesine çevirisi yapıllıken orijinal ifadelere sadık kalinmiştır.

Anahtar Kelimeler: Osmanlı Devleti, Almanya, Gümrük Tarifesi, Ithalat, İhracat

\begin{abstract}
The Ottoman State wanted to change the customs tariff that it had put into practice with the 1840 trade agreement it signed with Germany. Two important factors in this change attract attention. The first factor will be an increase in product prices and a decrease in customs duties. The second factor will be attempts to change the economic concept of the economy depending on the developments in the world conjuncture. The Ottoman State renewed the customs tariff with Germany after the 20 March 1862 trade agreement. Tariff was prepared as Ottoman Turkish. When translating to the Latin alphabet, the original statements were true.
\end{abstract}

Key Words: Ottoman State, Germany, Customs Tariff, Import, Export

\section{GíRiş}

Avrupa XIX. yüzyıl içinde siyasî, iktisadî ve askerî yönden olabildiğince derin ve kalıcı izlerin bırakılacağı gelişmeleri yaşamıştır. Aslında Avrupa'yı derinden etkileyecek bu gelişmelerin Amerika kıtasında Fransız-İngiliz iktisadî rekabeti ve buna bağlı olarak ortaya çıkan Fransız İhtilali olduğu gözlenmektedir. İhtilal sonrası Prusya Devleti genel olarak gelişmeleri izleme durumunda olmayı tercih etmiştir ${ }^{1}$.

Makalenin Geliş Tarihi: 12.11.2016, Kabul Tarihi: 30.03.2017

*. Yrd. Doç. Dr., Kastamonu Üniversitesi İ̈BF İktisat Bölümü, E-posta: fidanm51@yandex.com

1 Hermann Pinnow, Almanya Tarihi, C.II, Çev. Fehmi Baldaş, İstanbul 1940, s. 370-390

Akademik Bakış 
Almanya Şansölyesi Bismarck önceliğini Avrupa barışının devamını temin etmeye vermiştir ${ }^{2}$. Zira Bismarck'ı buna zorlayan sebeplerin çokluğu dikkat çekmektedir. Öncelikli olarak bu zorlanmada Fransa'nın Avrupa'daki yayılmacı girişimleri etken olacaktır³. Fransa'ya karşı Almanya'nın direnişi ile başlayan süreçte 1870-1871 Alman-Fransız savaşı Almanya Şansölyesi Bismarck'ı oldukça zorlayan bir faktör olarak karşımıza çıkmaktadır. Alman-Rus gerginliği de buna eklenecektir. Bir diğer etkili sebebin ise Almanya içinde Protestan-Katolik mezhepleri arasındaki mücadeleler olduğu görülmektedir .

Almanya, milli birliğini sağlama girişimleri ile eş zamanlı olarak hızlı büyüyen bir nüfusa sahip olmaya başlamıştır. Alman nüfusunun hızla artması Almanya'nın bir tarım ülkesinden bir ticaret ve sanayi ülkesine dönüşmesini tetiklemiştir. Bir taraftan milli birliğini koruma çabası içinde olan Almanya, diğer taraftan ise kapitalizmin getirmiş olduğu gücün de dışında kalmak istememektedir. Büyük bir hızla sanayileşen Alman endüstrisinin pazar ve hammadde ihtiyacını karşılama isteği, devletin dışarıya açılarak yayılmacı faaliyetler içerisine girme düşüncesi giderek ön plana çıkartmıştır ${ }^{5}$. XIX. yüzyılın sonlarında İngiltere ve Fransa gibi sanayileşmiş ülkeler dünya genelinde önemli yerleri sömürgeleri altına aldıkları için, geç sanayileşen ancak dünya pazarlarına da girmek isteyen Almanya'nın sömürge bulma çabaları uluslararası dengeleri bozan bir unsur olmuştur. İlk önceleri Afrika'da ve Pasifik'te daha az sorunlu olan bölgelerde arayış içerisine giren Almanya'nın, dağılmanın eşiğinde bulunan Osmanlı Devleti ile siyasi, askeri, ticari olarak her alanda kurmaya başladığı yoğun ilişkiler bu dengelerin bozulmasını da beraberinde getirecektir ${ }^{6}$.

Bütün bu gelişmeler çerçevesinde Almanya Şansölyesi Bismarck'ın Osmanlı Devleti ile ikili ilişkilere ve özellikle de iktisadî ilişkilere zaman ayıracak vakti olmayacaktır. Ancak Osmanlı Devleti ile Almanya arasında iktisadî ilişkilerin öteden beri devam ettiği de görülmektedir. İki devlet arasında ilk dostluk ve ticaret anlaşması 22 Mart 1761 tarihinde imzalanmıştır ${ }^{7}$. 31 Ocak 1790 tarihinde ise bu anlaşma elli yıl uzatılmıştır ${ }^{8}$. Bu anlaşma gereğince Fransız tüccarların sahip oldukları imtiyazlar artık Prusya tüccarlarına da bahşedil-

Akademik miştir. Anlaşma çerçevesinde ithalat ve ihracat için gümrük oranı \% 3 olarak belirlenmiştir?.
Rifat ÖNSOY, Türk-Alman İktisadî Münasebetleri (1871-1914), İstanbul 1982, s. 13-14 Fransa'yı buna iten sebeplerin başında ise Amerika'da İngiltere'yi yenmesine rağmen Amerikalılardan bağımsızlıkları sonrasında özellikle iktisadî beklentilerine karşılık bulamayışı gelecektir.

Fahir Armaoğlu, 19. Yüzyıl Siyasi Tarihi, TTK, Ankara 1999, s.334-380

İlber Ortaylı, Osmanlı Imparatorluğu'nda Alman Nüfuzu, İletişim Yay., s. 15-19

Ortaylı, a.g.e., 68-74

Muâhedât Mecmûası, TTK, c. 1, Ankara 2008, s. 83

Muâhedât Mecmûası, TTK, c. 1, Ankara 2008, s. 90

Muâhedât Mecmûası, TTK, c. 1, Ankara 2008, s. 86 
Prusya 1834'de kurulan Zollverein'e ${ }^{10}$ mensup devletler adına Osmanlı Devleti ile 10 Ekim 1840 tarihinde yeni bir ticaret anlaşması imzalamıştır. Bu anlaşma 1838 tarihli Osmanlı-İngiliz ticaret anlaşmasını esas almaktaydı. 1790 anlaşmasının aksine bu anlaşmada ithalat gümrüğü \% 5'e ihracat gümrüğü ise \% 12'ye yükseltilmiştirr ${ }^{11}$. Bâbıâli 1860'lara doğru yerli üretimi diş rekabetten korumak amacıyla 1838'den itibaren çeşitli devletler ile yapmış olduğu ticaret anlaşmalarını değiştirme yoluna gitmeye başlamıştır. Bu bağlamda Prusya'nın Zollverein'e mensup devletler adına Osmanlı Devleti ile imzaladığı anlaşması yenilenmiştir. Yeni anlaşmaya göre ithalattan alınan gümrük vergisi \% 5'ten \% 8'e yükseltilmiştir. İhracattan alınan gümrük vergisi ise \% 12'den \% 8'e indirilmiştir. Ancak ihracat gümrüğü, müteakip yıllarda her yıl \% 1 indirilmek suretiyle 8 yıl sonra \% l'e düşürülecekti' ${ }^{12}$.

\section{Gümrük Tarife Defterlerinin Hazırlanma Öncesindeki Durum}

XVII. yüzyıl ortalarına kadar Osmanlı Devleti'nin genelinde, diğer devlet tüccarlarının yapacakları ticaretler ahidnameler aracılığı ile düzenlenmekteydi. Buna göre yabancı tüccarların vermeleri gereken ticaret vergisi, oranı belirtilmeden sadece "âdet ve kanun üzere" belirli olan "mutâd rüsûm" olarak alınmaktayd $1^{13}$. Osmanlı Devleti bu uygulamayı, kendinden önceki diğer Türk devletleri döneminde \% 2 ila \% 5 oranında uygulandığı şekliyle ${ }^{14}$ değil de, kendi belirlediği esaslar dâhilinde, tebaa tüccarının vermekte olduğu ticaret vergilerini esas alarak uygulamıştır. Bu oran, yabancı devlet mahsulü ürünlerin ithalinden \% 2 ila \% 9, ihracattan ise \% 4 ila \% 9 olmuştur ${ }^{15}$.

10 Zollverein: 1815 Viyana Kongresi sonrasında Avrupa haritası büyük güçlerin çıkarlarına uygun bir şekilde yeniden düzenlenmişti. Oldukça karışık bir görünüme sahip bu yeni yapıda, uluslar parçalanmış hatta bazı yerlerde ise çeşitli ulusal topluluklar haline dönüştürülmüştü. O dönemde Almanya da 38 küçük devletçik ya da prensliğe bölünmüştü. Almanya'daki bu bölünmüşlükten dolayı gelişme imkanları oldukça kısıtlanmış kapalı ekonomiler ortaya çıkmıştı. Bu durumdan kurtulmak için, bir "Gümrük Birliği”'ne gereksinim vardı. Alman Gümrük Birliği (Zollverein) düşüncesi, Friedrich List tarafından "Ekonomik birlik ve siyasal birleşme, iki kardeş gibidirler, biri dünyaya gelmeden öteki doğuşa hazır olamaz" şeklinde dile getirilmiştir. List gümrük birliğinin sınırlarını bütün Avrupa kıtasını kapsayacak şekilde düşünmüş ise de bu fikri reddedilmişti. Daha sonra Zollverein 1834' de Prusya Maliye Bakanı Motz tarafından gerçekleştirilmiştir. Hermann Pinnow, a.g.e., s. 379-382; Florian Ploeckl, "The Zollverein and the formation of a Customs Union", University of Oxford Discussion Papers in Economic and Social History, Londra 2010, 84, s. 1-4; Karl Kunze-Karl Wolf, Grundwissen Geschichte, Ernst Klett Verlag, Stuttgart 1964, s. 54; İbrahim S. Canbolat, Uluslarüstü Sistem Avrupa Birliği, Alfa Yayınları, İstanbul 1998, s. 70 .

11 Muâhedât Mecmûası, TTK, c. 1, Ankara 2008, s. 94

12 BOA, A.DVN.MKL, Dosya No: 3, Gömlek No: 13, s. 12

13 I. Murat zamanında Cenevizlilere verilen Haziran 1387 tarihli ahidnamede, Yıldırım Bayezid'in Mart 1390 tarihli mektubu ile Kanuni Sultan Süleyman'ın Ekim 1540 tarihinde Venediklilere verdikleri ahidnamelerde bu hususların belirtildiğine dair bkz. Şerafettin Turan, "Osmanlı İmparatorluğu İle İki Sicilya Krallığı Arasındaki Ticaretle İlgili Gümrük Tarife Defterleri”, TTK Belgeler Dergisi, c. IV, sayı 2-8, Ankara 1969,, s. 79

Akademik Bakış 267 Cilt 10 Sayı 20 Yaz 2017 
Osmanlı Devleti bu uygulama ile, Avrupalı tüccarları Doğu Akdeniz'de tutmaya çalışarak, gerçekleşen ticaretten elde edilen gümrük vergileri ile hazineye gelir sağlamayı amaçlamıştır. Bunun yanı sıra kendisinden önce Avrupalı devletlere uygulanmakta olan ticari imtiyazları kaldırarak, konjonktüre ve kendi stratejisine uygun devletlere imtiyazlar vererek, bu devletleri birbirine karşı da kullanacaktır ${ }^{16}$.

Osmanlı Devleti'nde gerek yabancı devletlerden getirilen-götürülen gerekse de kara ve deniz yoluyla bir yerden bir yere nakledilen ürünler, şer'î ve örfî hukuka göre vergilendirilirdi ${ }^{17}$. Bu vergiler; çoğu kez düzensiz bir şekilde limanlarda, şehir ve kasaba girişlerinde, geçitlerde amediye, reftiye, mürûriye, bâc, ihtisâbiye, kalemiye, ruhsatiye, kantariye gibi değişik adlarla, bazı yerlerde yük ve denk, bazı yerlerde ise değer esası üzerinden alınmaktaydı ${ }^{18}$.

Avrupalı tüccarlar ile gerçekleştirilen ticaretin farklı mekânlarda yapılıyor olması, alınacak gümrük vergilerinin çeşitliliklerini de beraberinde getirmekteydi. Bu çeşitliliğin ortaya çımmasında mahalli gereksinimler ve halkın alışkanlıkları etkili olmaktaydı. Ticaretin farklı mekânlarda gerçekleşmesi ve yerel unsurların alışkanlıkları, benzer bir üründe bölgeden bölgeye farklılıkların ortaya çıkmasına neden olmaktaydı ${ }^{19}$. Avrupalı tüccarların Osmanlı bürokratlarının fazla gümrük vergisi aldığı yönündeki şikâyetlerinin çoğalması ile bu itirazları gidermek, gümrüklerdeki farklılıkları ortadan kaldırmak, gümrüklerde birlikteliği ve uygulamalarda kolaylıklar sağlamak maksadıyla, önce harici gümrüklerde tarife defterleri hazırlanmıştır ${ }^{20}$. Ahidnamelerle gümrük vergisi oranı devlet gelirinin azalması pahasına \% 3'e düşürülerek gümrüklerde birliktelik sağlanmaya çalışılışılmıştır²1. Ancak Osmanlı bürokratlarının Avrupalı

16 Halil İnalcık, Osmanl Imparatorluğu'nun Ekonomik ve Sosyal Tarihi 1300-1600, c. 1, İstanbul 2000, s. 236

17 Osmanlı Devleti şerî hukuk gereği İslam'da pazara getirilen üründen alınan \% 10 oranındaki uygulamayı zekat-ı 'âşir adı altında Müslüman ve ecnebi tüccarlara gümrük resmini \% 5 olarak uygulamıştır. Ancak zaman zaman resm miktarlarının arttırılması ve satış bedelinden devletin hisse alması bu verginin şerî̀ değil örfî olduğu şeklinde yorumlanmıştır. Abdurahman Vefik, Tekalif Kavaidi, c. I, İstanbul 1330, s. 53-54; Ahmet Tabakoğlu, a.g.e., İstanbul 1997, s. 258

Zafer Toprak, Türkiye Tarihi, c. 3, İstanbul 1997, s. 227; Sevda Özkaya, Süveyş Kanalı: 19. Yüzyılda Doğu Akdeniz'de Bir Rekabet Unsuru ( Osmanlı Arşiv Belgelerine Göre), Bilge-Kültür Sant Yay., İstanbul 2015, s. 448-55; XVI. yüzyılda ithalat ve ihracatta Osmanlı Devleti'nin aldığı vergilerin listesi için bkz. Şerafettin Turan, a.g.m., s. 166-169

19 Halil Sahillioğlu, "1763'te İzmir Limanı ve Ticaret Limanı ve İhracat Gümrüğü ve Tarifesi”, BTTD, sayı 8, İstanbul 1968, s. 53-57

20 Mübahat Kütükoğlu, Osmanl-İngiliz İktisadi Münasebetleri (1580-1838) I, Ankara 1974, s. 63

21 Gümrük vergisinin, Fransa ile yapılan Haziran 1673 tarihli ahidnamesi ile ilk defa \% 3'e indirildiği kabul edilmişse de aslında bundan daha evvel, 1666 da Cenevizlilerin Osmanlı Devleti ile yaptıkları uzun müzakereler sonucu almağa muvaffak oldukları ahidnamede, Cenova tebasının Osmanlı dahilinde verecekleri gümrük resmi \% 3 olarak tespit edilmiş, ayrıca iç ticaret vergilerinin de ödenmesi kararlaştırılmıştı. Bu antlaşmayı Venedik, Fransa İngiltere ve diğer Avrupa devletlerine verilen ahidnameler takip etmiştir. Şerafettin Turan, a.g.m., s. 81; Mübahat Kütükoğlu gümrük resmi oranının \% 3'e düşürülmesinin ilk defa İngilizlere verilen ahidname ile gerçekleştiğini, 1740 Fransız ahitnamesinden sonra ise bütün yabancı devlet 
tüccarlardan \% 3'den fazla gümrük talepleri devam etmiştir. Bu durumun devamı üzerine Osmanlı Devleti tarafından ticaret yapılan gümrüklere gönderilen emirler ile "bu uygulamaların yanlışlı̆̆ ve \% 3 üzerinden gümrük alınması" isteği bile durumun düzeltilmesine çare olmayacaktır²2. Osmanlı Devleti problemleri, gümrük tarife defterleriyle çözme yoluna gidecektir.

\section{Osmanlı-Alman Ticarî İlişkilerinde 1862 Tarihli Gümrük Tarife Defteri 1 - 1862 Tarihli Gümrük Tarife Defterinin Hazırlanma Süreci}

Osmanlı Devleti baştan beri tebaasının iaşesini olabildiğince ucuz, kaliteli ve bol olarak sağlamayı amaçlanmıştır ${ }^{23}$. Bu amaç doğrultusunda Osmanlı Devleti kendi memleketlerinde tüketilen zaruri ihtiyaç maddeleri ve stratejik öneme haiz maddelerin yabancı devlet tüccarı aracılığıyla ihracına kısıtlamalar getirmişti ${ }^{24}$. Ancak özellikle Avrupa'da ortaya çıkan gelişmeler Osmanlı Devleti'nin iktisadî politikalarında etkilerini hissettirmeye başlayacaktır. Yerli üretimin korunmasına yönelik tedbirler alma ihtiyacı hisseden Osmanlı Devleti, 1840 tarihli ticaret anlaşmaları ile dış ticaretinde gerilemeye sebep olan yönleri gidermeye çalışılacaktır. Bunun bir yansıması olarak Prusya ile 1840 tarihinde yapılan ticaret anlaşması da güncellenecektir.

XIX. yüzyılın ikinci yarısına gelindiğinde Osmanlı Devleti, Avrupalı devletler karşısında kadîm iktisadî politikaları ile mücadelede zorlanacaktır. Bunun bir sonucu olarak Osmanlı Devleti, "müsaadeye mazhar devletler" ile yapmış olduğu ticaret anlaşmalarını yenileme yoluna gidecektir. 1862 tarihinde Almanya ile imzalanan ticaret anlaşması bu mücadelenin bir yansıması niteliğindedir. Diğer devletler ile yapıldı̆̆ı gibi Almanya ile de gümrük tarife defterleri yenilenecektir.

tüccarlarının ayna hakka kavuştuğunu belirtmektedir. Mübahat Kütükoğlu, Tanzimat Devri Osmanlı-İngiliz Gümrük Tarifeleri, Tarih Enstitüsü Dergisi, sayı 4-5'den ayrı basım, İstanbul 1974, s. 335

22 Osmanlı Devleti'nde ithal ve ihraç ürünler ulaşacağı yere kadar çeşitli gümrüklerden geçmekteydi. Ancak bu ürünlerden sadece bir defaya mahsus bir yerde gümrük vergisi alınırdı. İlk gümrükte ödenen vergi sonrası verilen eda tezkeresi, daha sonraki gümrüklerde gösterilerek fazla gümrük vergisinin alınması önlenmeye çalışılmıştır. Ancak tüccarların ticarette ödediği \% 3 gümrük vergisinin fazla alınmasından dolayı sıkıntılar yaşamaktaydı. BOA, A.DVNS. DVE.d, Rusya Ahkam Defteri, 84/2, s. 26/95, 36/126, 36/142, 36/143, 36/144; Serhat Kuzucu, "Rusya Ahidname Defterine Göre XVIII. Yüzyılda Osmanlı-Rus Ticari İlişkilerinin Seyri", Tarih Araştırmaları Dergisi, C. 35, S. 59, Ankara 2016, s. 72

23 Osmanlı Devleti iaşe temininde herhangi bir sıkıntı yaşanmaması için, malın üretiminden tüketimine kadar her aşamada piyasaya müdahale etmiştir. Ayrıca iç piyasa talebinin karşılanması için ihracatta yasaklamalar, kısıtlamalar ve inhisarlar uygulamıştır. Bir başka deyişle iç piyasa talebini karşılamak için ihracatı zorlaştırıcı, ithalatı ise kolaylaştırıcı ve teşvik edici davranıyordu. Mehmet Genç, Osmanlı Imparatorluğunda Devlet ve Ekonomi, Ötüken Yay., İstanbul 2000, s. 53-59; İ. Wallerstein- Reşat Kasaba, "İncorporation İnto The Word Economy: Change İn The Structur of The Ottoman Empire 1750-1839”, ODTÜ Gelişme Dergisi, c. VIII/1-2, Ankara 1981, s. 548

24 İhracı yasak ürünler arsında buğday, güherçile, demir, donyağı, kereste gibi ürünler bulunmaktaydı. Ziya Kazıcı, Osmanlılarda İhtisap Müessesesi, İstanbul 1987, s. 214; Ömer C. Sarc, "Tanzimat ve Sanayimiz", Tanzimat I, İstanbul 1940, s. 443 
Yenilenen bu tarife defteri, Osmanlı Devletinin kadim iktisadî anlayışındaki değişimi de yansıtmaktadır. Bâbıâli'nin yapmaya çalıştığı aslında himayeci gümrük anlayışına geçme çabasıdır²5. Zira tarife defterinde yer alan 608 adet üründen 130 adedinin rayice bırakılması bunun bir göstergesi durumundadır. Ürünlerin rayice bırakılmasında öncelikle ürünün gümrük vergisine esas olacak kıymetinin hesaplanmasındaki ihtilafların giderilmesi düşüncesinin etkili olduğu anlaşılmaktadır. Diğer taraftan ürün fiyatındaki iniş ve çıkışlardan hazinenin zararını azaltmak üzere ürünler rayice bırakılarak, güncel değerleri üzerinden gümrük vergisi alınmak istenmiştir ${ }^{26}$.

Tarife defterinin hazırlanma gerekçesi olarak 'her nev i emti a ve eşya üzerine edâsı lazım gelen gümrük rüsümâtıçün ... ol vaktin rayicine göre tanzim olunmuş olan" ve "1847 senesi Mart ayı ile 1855 senesi 13 Mart'a kadar" geçerli olan tarifenin "müddeti münkaziyye olmuş" olmısı gösterilmiştir. Diğer bir ifade ile süresi sona eren tarifenin yenilenmesi istenmektedir. Bu çerçevede "tarafeyn tâlib bulunduğuna binâen" denilerek iki Devletin istemesi sonrasında "taraf-i devlet-i aliyyeden ve Purusya sefâreti canibinden" görevliler yeni tarife defterini hazırlamışlardır ${ }^{27}$.

\section{2- 1862 Tarihli Gümrük Tarife Defterinin Muhtevası}

Tarife defteri "zü-nasrâyin ta bir olunur Cermanya" ifadesi ile başlamaktadır ${ }^{28}$. Bu defterin hazırlanma gerekçeleri sıralandıktan sonra üç ayrı liste hazırlanmıştır. Birinci listede Cermanya tüccarının satın alacağı "Memalik-i Mahrûsa-i Şâhâne Mahsûlâtı" olarak ifade edilen Osmanlı Devleti mahsulü olan ürünler, kıymetleri ve gümrük vergisi miktarları liste halinde verilmiştir. "Memalik-i Mahrûsa-i Şâhâne Mahsûlâtı" ifadesi ile geniş bir coğrafyada bulunan Osmanlı şehirlerindeki ürünlerinin ifade edildiği düşünülmektedir. Bu listede 383 aded ürün yer almaktadır. Osmanlı Devleti mahsülü olan 61 aded ürün rayice bırakılmıştır ${ }^{29}$.

İkinci listede "Asitâne Mahsûlâtı" olarak ifade edilen İstanbul mahsülü ürünler, kıymetleri ve gümrük vergisi miktarları liste halinde verilmiştir ${ }^{30}$. "Asitâne Mahsûlâtı" ifadesi ile İstanbulda üretilen veya İstanbula getirilerek burada satılan ürünlerin ifade edildiği düşünülmektedir. Asitâne Mahsûlâtı olan

Akademik 76 ürün listede yeralmıştır. Bu ürünlerden 4 adedi rayice bırakılmıştır.

Üçüncü listede ise "Zü-nasrâyin ta bir olunur Cermanya'nın memâlik-i münfikası mahsûlâtı" olarak ifade edilen Cermanya mahsülü ürünler, kıymetleri ve

25 Emine Kıray, Osmanlı'da Ekonomik Yapı ve Dış Borçlar, İletişim Yay., İstanbul 1995, s. 75-80; Rifat Önsoy, a.g.e., s. 36-38

26 Önsoy, a.g.e., s. 36

27 BOA, A. DVN. MKL., Dosya No: 3, Gömlek No: 13, s. 1

28 Osmanlı Devleti'nin Almanya'ya "zü-nasrâyin ta bir olunur Cermanya"ifadesi ile hitap etmesinin sebebinin Almanya'nın siyasi birlikteliğini sağlamak için Katolik-Protestan mezheplerini bir arada tutma mücadelesinden olduğu düşünülmektedir.

29 BOA, A. DVN. MKL., Dosya No: 3, Gömlek No: 13, s. 1-12

30 BOA, A. DVN. MKL., Dosya No: 3, Gömlek No: 13, s. 12-14 
gümrük vergisi miktarları liste halinde verilmiştir. Bu listede 149 aded ürün yeralmaktadır. Bu ürünlerden 65 adedi rayice bırakılmıştır.

Tarife defterinde yukarıda ifade edilen üç listede toplam 608 ürün liste halinde verilmiştir. Yine bu listelerde yer alan 130 aded ürün ise rayice bırakılmıştır. Tarifede yeralan Almanya'ya ihraç edilen mallar arasında kurutulmuş gıdalar, palamut, yağlı tohumlar, pamuk ve pamuklu ürünler, yün ve yünlü ürünler, hububat, deri ve boya hammaddeleri dikkat çekmektedir. Almanya'dan ithal edilen ürünler arasında ise pamuklu ve yünlü dokumalar, iplikler, hazır kıyafetler, ayakkabılar, süs eşyaları ve oyuncaklar, kağıt, işlenmiş deri ve çanta, hırdavat, esnaflar için alet ve edevatlar yer almaktadır. (bkz. Ek 1)

Tablo-1 Osmanlı ve Almanya Ürünleri

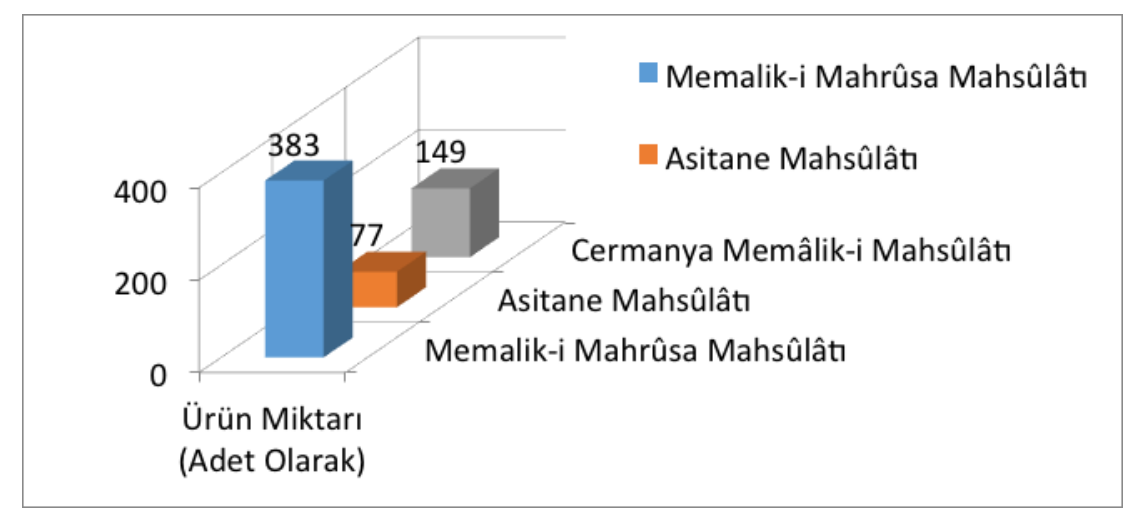

Anlaşma gereği Almanya tüccarının kendi memleketine ait “Cermanya'nın ... mahsûlât-ı arziyye ve harsiyye ve sanâ iyyesinden" olan hububat gibi topraktan elde edilecek ürünleri, yöresel ürünleri ve sanayi ürünlerini Osmanlı Devleti'ne getirebilecekleri; Osmanlı Devleti'nin "ğayr-ı ez memnû ât" ilan etmediği yasaklanmamış "memâlik-i mahrûsa-i şâhâne mahsûlât-ı arziyye ve hirsiyye ve sanâ iyyesinden" olan emtia ve eşyayı satın alarak ister kendi memleketlerine isterse de "diyâr-1 âhara" yani başka memleketlere yenilenen ticaret anlaşması gereğince \% 8 gümrük vergisi ödeyerek götürebilecekleri ifade edilmiştir.

Tüccarların aldıkları ve sattıkları ürünler "mu ahede-i cedide iktizasınca" iskele kıymetinden olması "meşrût bulunmuş oldı̆̆ından" yani şarta bağlanmıştır. Osmanlı Devleti'nde kullanılan yüzlük mecidiye altını yüz guruş olarak kabul edilerek ürün "kıymetlerini iskele kımmetlerine indirmek"ve ürünün kıymetinden "yüzde onu tenzil olunduktan sonra" ürünün "sâfi klymetleri üzerinden resm gümrükleri ta yin ve ta 'rif" olması sağlanacak ve gümrük vergisi hesaplanarak alınmış olacaktır. Osmanlı Devleti gümrük tarife defterinde "îhrâcat içün" \% 8 sekiz olarak belirlediği gümrük vergisi oranının bu tarife defterinin "yalnı birinci senesi" için geçerli olduğunu ifade etmiştir. "íkinci sene ibtidâsında" yani ikinci sene başında \% 8

Akademik Bakış 271 Cilt 10 Sayl 20 Yaz 2017 
oranından \% 1 lik bir indirimle \% 7'ye "kezâlik" bir sene sonra \% 6'ya indirilerek "sekizinci senede"\% l'e "ininceye değin her sene"\% l'i "tenzîl idilerek"yani indirilecektir. Sekizinci sene ve ondan sonraki seneler \% 1 oranı ile gümrük vergileri hesaplanarak "gümrüklerde bu vechle icrâ kılınacaktır"yani gümrük vergisi alınacaktır.

İhracat ürünlerinden olup tarifede ismi olmayan, olsa bile "behâsı ta yin olunmayarak râyice birağılmış" olan "emti a ve eşya râyic ve kıymetine" göre "râyic vakt üzere" kımetinden \% 10'u indirildikten "tenzîl olunduktan" sonra geriye kalacak "behâsından" yukarıda belirlendiği gibi her sene \% 1 indirimi ve sekizinci ve sonrasında ise \% 1 oranında gümrük vergisi alınacaktır. "Zü-Nasârin"yani Almanya mahsülü olup Osmanlı Devleti'ne ithal edilen ürünlerden daima \% 8 gümrük vergisi alınacaktır. İsmi tarife defterinde yazılmayan, yazılsa bile kıymeti rayice bırakılan Almanya "emti‘a ve eşyasından" ise "kımetinden yüzde on tenzil" olunduktan sonra \% 8 oranında gümrük vergisi alınacaktır. Almanyalı tüccarların ödemesi gereken gümrük vergisi miktarı ürünün kuruş değeri üzerinden hesaplanmıştır. Ancak Osmanlı Devleti, Almanyalı tüccarlardan ödemelerini mecidiye altını üzerinden yapmalarını istemiştir. Buna göre tüccarlardan "işbu idhâlat ve ihrâcatdan alınacak" gümrük vergisi altın ve gümüş para olarak "tahsîl" olunacaktır. Osmanlı Devleti bu çerçevede Alman tüccarlara birtakım kolaylıklar getirmişitir:

1- Yüzlük mecidiye altunı"ve onun kısmı olan "altun ve gümüş" para 100 kuruş;

2- "Beş aded gümüş mecidiye" ise "bir altun mecidiyeye bedelle" yine 100 kuruş;

3- Tüccar 1 altın mecidiye 100 kuruş olarak "bir altun mecidiyeye bedelle yüz guruş hesabıyla" mecidiye altını "darb-hâne fiyatı" esas alınarak gümrük vergisi "peşinen" alınacaktır.

4- Almanyalı tüccar 1 altın mecidiye 100 kuruş olmak şartıyla "borsada" parasının "en ziyâde yüksek" fiyatı üzerinden gümrük vergisini ödeyebilecktir. Bu son durum yanlızca İstanbul gümrüklerinde geçerli olacak diğer gümrüklerde ise "işbu kaimenin suret-i te'diyesi méelesi şimdilik mevkuf" yani sonraya bırakılacaktır. Gerekli görülür ise "Bâb-ı âlî ile devlet-i meşâr-ı ileyhâ" sefirleri aralarında müzakere yaparak karara bağlayacaklardı.

Taşra gümrüklerinde Almanya tüccarı yukarıda belirtilen şartlara göre gümrük vergisini ödeyecektir.

Bu tarifenin süresi 'bin ikiyüz seksenbeş senesinde vâki 'olacak Martın sekizinci ve bin sekizyüz altmış dokuz senesi alafıranga Martın yirminci gününe"kadar yani 20 Mart 1869 senesine kadar geçerli olacaktır. Bu sürenin sona ereceği sene gerek Osmanlı Devleti gerekse Almanya tarifeyi yenileme talabinde bulunmaz ise süresi "yedi sene dahâ" devam edecektir.

Tarifenin hazırlanması iki devlet adına kurulan komisyon tarafından hazırlanmıştır. Komisyonda Prusya adına Baron Th. Deresta, Osmanlı Devleti adına ise İsmail Paşa başkanlık etmiştir. 


\section{SONUÇ}

Almanya milli birliğini oluşturma gayretleri içinde olduğu bu tarihlerde, Osmanlı Devleti ile iktisadî ilişkilerine diğer devletler kadar önem vermemekteydi. Ancak iki devlet arasında hiç de azınsanmayacak bir ticari potansiyelin varlığı dikkat çekmektedir. Tarifede yer alan ürünler incelendiğinde Osmanlı Devleti'nden Almanya'ya gönderilecek ürünlerin fazlalığı göze çarpmaktadır. Almanya'dan Osmanlı'ya getirilen ürün miktarı ise daha az miktardadır.

Osmanlı Devleti'nden Almanya'ya gönderilen ihraç ürünleri arasında Anadolu'dan elde edilen 460 kalem ürün bulunmaktadır. Bu ürünler arasında boya hammaddeleri, yaş/kuru meyve ve sebzeler, giyim üretiminde kullanılacağı düşünülen pamuk, keten gibi hammaddelerin yanı sıra işlenmemiş deri, Anadolu'da üretilen giyim ve ayakkabı çeşitleri dikkat çekmektedir. İhraç edilen bu ürünler, Osmanlı Devleti'nin sanayileşme çaba ve gayretlerine rağmen Almanya'ya daha ziyade hammadde ağırlıklı bir ürün çeşitliliğini ihraç ettiğini göstermektedir.

Almanya'dan Osmanlı Devleti'ne ithal ürünleri arasında 149 kalem ürün bulunmaktadır. Almanya mahsülü ürünler, Osmanlı mahsülü ürünlere göre daha fazla işlenmiş ürün içermektedir. Bu ürünler arasında iğne, çatal, kaşık, tırpan, orak, ustura gibi çelik ve demirden elde edilen ürünler bulunmaktadır. İşlenmiş ağaç ürünleri, fincan ve mücevherat da dikkat çen ürünler arasında bulunmaktadır. Ayrıca işlenmemiş çelik Osmanlı Devleti tarafından ithal edilen ürünler arasında bulunmaktadır. Alman mahsülü olan dokuma kumaş ve ayakkabı çeşitlerinin yanısıra kağıt, şab ve içki çeşitleri de bulunmaktadır. Bu durum ise bize Almanya'nın milli birliğini sağlama mücadelesi verirken karşılaştığı zorluklara rağmen sanayileşme ve seri üretim çalışmalarını devam ettirdiğini göstermektedir.

Bu tarifede, basit bir şekilde ihraç ve ithal ürünlerinin her birinin kantar, kıyye, zira', top, çift, deste, miskal, kutu, sandık gibi ticarette kullanılan birimleri üzerinden değerleri ve alınacak gümrüğü gösterilmiştir. Böylelikle Osmanlı Devleti'nin bütününde uygulanan gümrük tarifesinde birliktelik sağlanmaya çalışılmıştır. Bazı ürünler ise değer ve kıymet olarak ifade edilmemiş ve rayice bırakılmıştır. Rayice bırakılan ürünler günlük değerleri üzerinden belirlenen üsül ve miktarlara göre vergilendirilmiştir. Himayeci bir gümrük anlayışına göre tanzim edilen 1862 tarihli tarife defteri ile Alman tüccarlarının Osmanlı Devleti'ne getirdikleri ürünler için \% 8 gümrük vergisi belirlenmiştir. Alman tüccarların Osmanlı Devleti'nden alıp götürdükleri ürün için ise \% 8 olarak belirlenen rakam kademeli olarak her yıl \% 1 düşürülerek 8 yılın sonunda \% 1 olarak vergilendirilecektir.

Gümrük resminin ödenmesinde, 1 mecidiye altını 100 kuruş üzerinden işlem göreceği belirtilmiştir. Alman tüccarlara Osmanlı Devleti'nin değişik yer-

Akademik Bakış 273 Cilt 10 Sayı 20 Yaz 2017 
lerinde yapacakları ticaret sonrası ödemeleri gereken gümrük vergisi için ödeme kolaylıkları da sağlanmıştır.

1862 tarifesinde ürünün nevi ve cinsine göre itinalı bir sıralama bulunmamaktadır. Ancak bu ürünleri kendi içinde meşrubat ve müskirat, baharatlar, taze ve yaş meyveler, maden ve madeni aletler, hayvani maddeler, kürk ve deriler, iplik ve kumaşlar şeklinde sınıflandırmamız mümkündür. Tarifenin başında tarifenin hazırlanma sebepleri ifade edilmiştir. Tarifenin sonunda ise tarife ile ilgili açıklayıcı bilgiler bulunmaktadır. (Bkz. Ek I)

\section{KAYNAKLAR}

BOA, A. DVN. MKL., Dosya No: 3, Gömlek No: 13

BOA, A.DVNS.DVE. d, Rusya Ahkam Defteri, 84/2

ARMAOĞLU, Fahir, 19. Yüzyıl Siyasi Tarihi, TTK, Ankara 1999

CANBOLAT, İbrahim S., Uluslarüstü Sistem Avrupa Birliği, Alfa Yayınları, İstanbul 1998 GENÇ, Mehmet, Osmanlı Imparatorluğunda Devlet ve Ekonomi, Ötüken Yay., İstanbul 2000

INALCIK, Halil, Osmanlı Imparatorluğu'nun Ekonomik ve Sosyal Tarihi 1300-1600, c. 1, İstanbul 2000

KAZICI, Ziya, Osmanlılarda İhtisap Müessesesi, İstanbul 1987

KIRAY, Emine, Osmanlı'da Ekonomik Yapı ve Dış Borçlar, İletişim Yay., İstanbul 1995 KUNZE, Karl - WOLF, Karl, Grundwissen Geschichte, Ernst Klett Verlag, Stuttgart 1964 KUZUCU, Serhat, "Rusya Ahidname Defterine Göre XVIII. Yüzyılda Osmanl-Rus Ticari İlişkilerinin Seyri", Tarih Araştırmaları Dergisi, C. 35, S. 59, Ankara 2016, s. 63-83 KÜTÜKOĞLU, Mübahat, Osmanl-Ingiliz İktisadi Münasebetleri (1580-1838) I, Ankara 1974

--, Tanzimat Devri Osmanlı-İngiliz Gümrük Tarifeleri, Tarih Enstitüsü Dergisi, sayı 4-5'den ayrı basım, İstanbul 1974, s. 335

MUÂHEDÂT MECMÛASI, TTK, c. 1, Ankara 2008

ORTAYLI, İlber, Osmanlı Imparatorluğu'nda Alman Nüfuzu, İletişim Yay, İstanbul 1983

ÖNSOY, Rifat, Türk-Alman İktisadî Münasebetleri (1871-1914), Enderun Kitabevi, İstanbul 1982

ÖZKAYA, Sevda, Süveyş Kanalı: 19. Yüzyılda Doğu Akdeniz'de Bir Rekabet Unsuru ( Osmanlı Arşiv Belgelerine Göre), Bilge-Kültür Sant Yay., İstanbul 2015

PINNOW, Hermann, Almanya Tarihi, C.II, Çev. Fehmi Baldaş, İstanbul 1940

PLOECKL, Florian, "The Zollverein and the formation of a Customs Union", University of Oxford Discussion Papers in Economic and Social History, Londra 2010, 84, s. $1-44$ 
SAHILLIOĞLU, Halil, “1763'te İzmir Limanı ve Ticaret Limanı ve İhracat Gümrüğü ve Tarifesi”, BTTD, sayı 8, İstanbul 1968

SARC, Ömer C., "Tanzimat ve Sanayimiz", Tanzimat I, İstanbul 1940, s. 443

TABAKOĞLU, Ahmet, Türk İktisat Tarihi, İstanbul 1997

TOPRAK, Zafer, Türkiye Tarihi, c. 3, İstanbul 1997

TURAN, Şerafettin, "Osmanlı İmparatorluğu İle İki Sicilya Krallığı Arasındaki Ticaretle İlgili Gümrük Tarife Defterleri", TTK Belgeler Dergisi, c. IV, sayı 2-8, Ankara 1969

VEFIK, Abdurahman, Tekalif Kavaidi, c. I, İstanbul 1330

WALLERSTEIN, İ. - KASABA, Reşat, "İncorporation İnto The Word Economy: Change İn The Structur of The Ottoman Empire 1750-1839", ODTÜ Gelişme Dergisi, c. VIII/1-2, Ankara 1981, s. 548

\section{EK 1 - Osmanlı Devleti ile Almanya Devleti Arasında İmzalanan 1862 Gümrük Tarife Defteri}

Zü-nasrâyin ta'bir olunur Cermanya'nın memâlik-i münfikası mahsûlât-1 arziyye ve harsiyye ve sanâ'iyyesinden olarak memâlik-i mezkûre tüccâr ve teb‘asının ğayr-1 ez memnû'ât memalik-i mahrûsa-i şâhâneye getürdükleri ve memâlik-i mahrûsa-i şâhâne mahsûlât-1 arziyye ve hırsiyye ve sanâ'iyyesinden bi'l-mübâya'a kendü memleketlerine ve-yâhûd diyâr-1 âhara nakl içün teb'a-i merkûmenin ve gerek vekillerinin memalik-i şâhânenin her bir mahallinden mübâya'a ittikleri her nev‘ emti'a ve eşya üzerine edâsı lazım gelen gümrük rüsümâtıçün bin sekiz yüz kırk yedi sene-i milâdiyesi teşrin-i evvelinden bin sekiz yüz elli beş senesi martının on üçüncü gününe kadar ol vaktin rayicine göre tanzim olunmuş olan ta'rifenin müddeti münkaziyye olmuş ise de ba'zı esbâb-1 mâni’a haylûletiyle tecdîdi te'hîr eylemiş olduğuna ve ber-mûceb mu'âhede tecdîd ta'rifeye tarafeyn tâlib bulunduğuna binâen taraf-1 devlet-i 'aliyyeden ve Purusya sefâreti cânibinden ta'yin kılınan me'murlar bi' d-def'ât ictima' iden bir kıt’a ta'rife defteri tanzim olunmuş olmağla memâlik-i mahrûsa ile zü-nasrâyin memâlik-i mahsûlât ve emti'asının ber-vechi âti ta'rifelerine ibtidâr olunur

\section{Memalik-i Mahrûsa-i Şâhâne Mahsûlâtı}

\begin{tabular}{|c|c|c|c|}
\hline & ÜRÜN CINSİ & KIYMETI & GÜM. MIKTARI \\
\hline 1 & $\begin{array}{l}\text { Ala } \text { Cehre }^{4} \text { Ankara ve Kaysariya ve } \\
\text { Tokad ve İskilib A'lâ }\end{array}$ & Kıyye 1 G 4 P $20^{5}$ & Güm. G 0 P 33 \\
\hline 2 & $\begin{array}{l}\text { Ala Cehre ve İskilib ve Kaysariya ve } \\
\text { Tâğ-1 Cerbi-yi Anadolu ve ednâ }\end{array}$ & Kiyye 1 G 2 P 90 & Güm. G 0 P 23 \\
\hline 3 & Ala Cehre Rum İli bi'l-cümle & Kiyye 1 G 1 P 30 & Güm. G 0 P 10 \\
\hline 4 & $\begin{array}{l}\text { Afyonkarahisar ve Geyve ve Amasya } \\
\text { ve Ankara bi'l-cümle }\end{array}$ & Kiyye 1 G 200 P 0 & Güm. G 16 P 0 \\
\hline 5 & Üzüm Kara Bürde Çekirdeksiz & Kantar 1 G 231 P 40 & Güm. G 18 P 51 \\
\hline
\end{tabular}

Akademik Bakış 275 Cilt 10 Say1 20 Yaz 2017 


\begin{tabular}{|c|c|c|c|c|}
\hline & 6 & $\begin{array}{l}\text { Urla ve Çeşme ve Aydın ve Manisa ve } \\
\text { Kara Oğlak ve Tire Üzüm Rezzâki }\end{array}$ & Kantar 1 G 160 P 70 & Güm. G 12 P 85 \\
\hline & 7 & $\begin{array}{l}\text { Urla ve Çeşme ve Yerlü mahsuli } \\
\text { Çekirdeksiz Üzüm Rezzâki }\end{array}$ & Kantar 1 G 176 P 40 & Güm. G 14 P 91 \\
\hline & 8 & Karaburun ve Sekune Üzüm Rezzâki & Kantar 1G 193 P 0 & Güm. G 15 P 44 \\
\hline & 9 & Üzüm Beğlerce & Kantar 1 G 70 P 70 & Güm. G 5 P 65 \\
\hline & 10 & Üzüm Kuş & Kantar 1 G 160 P 70 & Güm. G 12 P 85 \\
\hline & 11 & Siyah Üzüm Aydın ve Tire & Kantar 1 G 45 P 0 & Güm. G 3 P 60 \\
\hline & 12 & Üzüm İstanköy Rezzâkisi & Kantar 1 G 168 P 50 & Güm. G 10 P 28 \\
\hline & 13 & Üzüm Mândâlyân ve Sisam & Kantar 1 G 64 P 30 & Güm. G 5 P 14 \\
\hline & 14 & Alaca-i Manisa & $\begin{array}{l}\text { Denk } 1 \text { Top } 100 \\
\text { G } 385 \text { P } 70\end{array}$ & Güm. G 30 P 85 \\
\hline & 15 & Alaca-i Haleb & Top 1 G 38 P 50 & Güm. G 3 P 8 \\
\hline & 16 & Alaca-i Tire ve Burd & Top 1 G 5 P 20 & Güm. G 0 P 41 \\
\hline & 17 & Alaca-i Şam döknâbi ve Cenâri & Top 1 G 70 P 70 & Güm. G 5 P 65 \\
\hline & 18 & İbrahimiye & Top 1 G 57 P 90 & Güm. G 4 P 63 \\
\hline & 19 & Penbe-i hâm Anadolı Kıbrıs ve Boğaz & Kantar 1 G 270 P 0 & Güm. G 21 P 60 \\
\hline & 20 & Penbe-i hâm Rumili & Kantar 1 G 257 P 20 & Güm. G 20 P 57 \\
\hline & 21 & $\begin{array}{l}\text { Palamut Ayvacık ve Ezine ve Midillü } \\
\text { ve Kemer ve fevme-i Sultaniye }\end{array}$ & Kantar 1 G 51 P 40 & Güm. G 4 P 11 \\
\hline & 22 & $\begin{array}{l}\text { Palamut Aydın ve Uşâk ve Gördes ve- } \\
\text { sair İzmir iskelesine tenzil olunan }\end{array}$ & Kantar 1 G 45 P 0 & Güm. G 3 P 60 \\
\hline & 23 & $\begin{array}{l}\text { Boğasi-i sahye ve Denizli elvane ve } \\
\text { alacası }\end{array}$ & Kiyye 1 G 14 P 20 & Güm. G 1 P 13 \\
\hline & 24 & Balya-i Bilecik & Çift 1 G 38 P 50 & Güm. G 3 P 8 \\
\hline & 25 & Döşeme balya-i Bilecik & Çift 1 G 57 P 90 & Güm. G 4 P 63 \\
\hline Qpori & 26 & Döşeme balya-i Üsküdar & & Rayicinden \\
\hline & 27 & Telli balya-i Bilecik & Çift 1 G 209 P 0 & Güm. G 16 P 72 \\
\hline Bakış & 28 & $\begin{array}{l}\text { Tiftik ve fenk-i Ankara ve Konya ve } \\
\text { Kastamonı ve Gerede ve Beğbazârı }\end{array}$ & Kiyye 1 G 20 P 50 & Güm. G 1 P 64 \\
\hline $\begin{array}{r}\text { Cilt } 10 \\
\text { Say1 } 20 \\
\text { Yaz } 2017\end{array}$ & 29 & $\begin{array}{l}\text { Paladon ta'bir olunur bi'l-cümle ve } \\
\text { herim }\end{array}$ & & Rayicinden \\
\hline & 30 & Tutkal & Kiyye 1 G 2 P 50 & Güm. G 0 P 20 \\
\hline & 31 & Sa'leb Anadolı & Kiyye 1 G 19 P 30 & Güm. G 1 P 54 \\
\hline & 32 & Sa'leb Rumili & Kiyye 1 G 12 P 90 & Güm. G 1 P 3 \\
\hline & 33 & Cild-i tavşan Anadolı & Aded 100 G 157 P 30 & Güm. G 12 P 58 \\
\hline & 34 & Cild-i tavşan Rumili & Aded 100 G 94 P 40 & Güm. G 55 P 7 \\
\hline & 35 & Bi'l-cümle çemşir Anadolı ve Rumili & Kantar 1 G 12 P 60 & Güm. G 1 P 0 \\
\hline
\end{tabular}




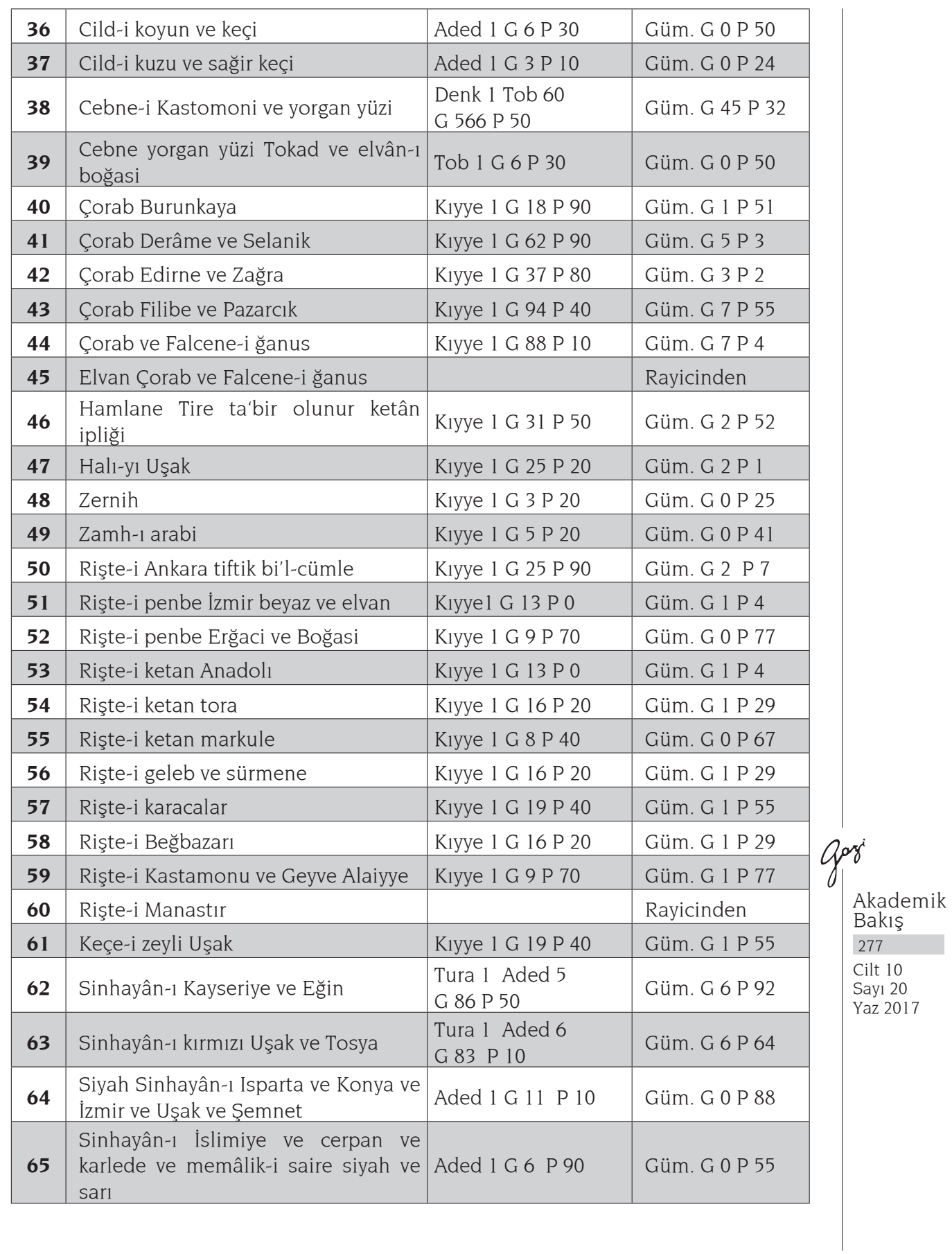




\begin{tabular}{|c|c|c|c|c|}
\hline & 66 & Al Sinhayân-1 Rumili & Aded 1 G 13 P 90 & Güm. G 1 P 11 \\
\hline & 67 & Sinhayân-ı Erkeli ve Balıkesiri & Aded 1 G 12 P 50 & Güm. G 1 P 0 \\
\hline & 68 & Şem-i asel külçe & Kıyye 1 G 18 P 40 & Güm. G 1 P 47 \\
\hline & 69 & Mazı bi'l-cümle a'lâ ve ednâ & Kantar 1 G 296 P 0 & Güm. G 23 P 68 \\
\hline & 70 & $\begin{array}{l}\text { Memâlik-i mahrûse-i şâhânede hâsıl } \\
\text { olan işlenmiş a'lâ yaprak ta'bir olu- } \\
\text { nur beyaz ketre }\end{array}$ & Kantar 1 G 24 P 0 & Güm. G 1 P 84 \\
\hline & 71 & $\begin{array}{l}\text { Memâlik-i mahrûse-i şâhânede hâsıl } \\
\text { olan kayde ta'bir olunur orta ketre }\end{array}$ & Kantar 1 G 9 P 10 & Güm. G 0 P 72 \\
\hline & 72 & $\begin{array}{l}\text { Memâlik-i mahrûse-i şâhânede hâsıl } \\
\text { olan ednâ mahluta ta'bir olunur ketre }\end{array}$ & Kantar 1 G 6 P 50 & Güm. G 0 P 56 \\
\hline & 73 & Mahmuze & Kantar 1 G 138 P 0 & Güm. G 11 P 4 \\
\hline & 74 & Firın camus & Çift 100 G 262 P 80 & Güm. G 21 P 6 \\
\hline & 75 & Firın bakar & Çift 100 G 240 P 0 & Güm. G 18 P 40 \\
\hline & 76 & Geyik boynuzu & Kantar 1 G 4 P 0 & Güm. G 0 P 32 \\
\hline & 77 & Dana mastaki & Kantar 1 G 98 P 50 & Güm. G 7 P 77 \\
\hline & 78 & Gül yağı & Menfeli 1 G 11 P 80 & Güm. G 0 P 94 \\
\hline & 79 & Harir Trablus kuşağı & Kiyye 1 G 262 P 80 & Güm. G 21 P 2 \\
\hline & 80 & Asfur Anadolı & Kantar 1 G 10 P 50 & Güm. G 0 P 84 \\
\hline & 81 & Kök Boya-i Anadolı & Kantar 1 G 197 P 0 & Güm. G 15 P 76 \\
\hline & 82 & Kaneki & Kantar 1 G 65 P 70 & Güm. G 5 P 65 \\
\hline & 83 & Muskili & $\begin{array}{l}\text { Varil } 1 \text { Kiyye } 30 \\
\text { G } 3500 \text { P } 0\end{array}$ & Güm. G 280 P 0 \\
\hline & 84 & Kemik & Kantar 1 G 10 P 0 & Güm. G 0 P 80 \\
\hline Gori & 85 & Kituni kebir a'lâ ve ednâ & $\begin{array}{l}\text { Kağıd } 1 \text { Aded } 4 \\
\text { G } 113 \text { P } 30\end{array}$ & Güm. G 9 P 6 \\
\hline $\begin{array}{r}\text { Akademik } \\
\text { Bakış }\end{array}$ & 86 & Kituni sağir & $\begin{array}{l}\text { Deste } 1 \text { Aded } 12 \\
\text { G } 113 \text { P } 30\end{array}$ & Güm. G 9 P 6 \\
\hline $\begin{array}{c}278 \\
\text { Cilt } 10\end{array}$ & 87 & Kituni mecidiyye ta'bir olunur & $\begin{array}{l}\text { Kağıd } 1 \text { Aded } 4 \\
\text { G } 66 \text { P } 70\end{array}$ & Güm. G 5 P 33 \\
\hline Yaz 2017 & 88 & Sade futa-i hâm & Çift 1 G 46 P 70 & Güm. G 4 P 73 \\
\hline & 89 & Peştamal Bursa & Çift 1 G 16 P 70 & Güm. G 1 P 33 \\
\hline & 90 & Kuşak tunusi & Aded 1 G 46 P 70 & Güm. G 3 P 73 \\
\hline & 91 & Kıbrısi oda takımı & & Rayicinden \\
\hline & 92 & Kıbrısi yorgan yüzü ve sofra & Aded 1 G 10 P 0 & Güm. G 0 P 80 \\
\hline & 93 & Kıbrısi döşek ve şilte & Aded 1 G 13 P 30 & Güm. G 1 P 6 \\
\hline & 94 & Kıbrısi kassale ve yasdık ve boğça & Aded 1 G 13 P 30 & Güm. G 1 P 6 \\
\hline
\end{tabular}




\begin{tabular}{|c|c|c|c|c|}
\hline 95 & Kıbrısi seblecik & Aded 1 G 13 P 30 & Güm. G 1 P 6 & \\
\hline 96 & Fotani-i Şam & Tob 1 G 66 P 70 & Güm. G 5 P 33 & \\
\hline 97 & Fotani-i Haleb & Tob 1 G 53 P 30 & Güm. G 4 P 26 & \\
\hline 98 & $\begin{array}{l}\text { Kök boya-i Kıbrısi ve beryene'ş-şam } \\
\text { ve tarblusi-yi Arab }\end{array}$ & Kantar 1 G 133 P 30 & Güm. G 10 P 66 & \\
\hline 99 & Ketre-i Basra ednâ & Kiyye 1 G 1 P 40 & Güm. G 0 P 11 & \\
\hline 100 & Ketre-i Ba'dad ednâ & Kıyye 1 G 3 P 40 & Güm. G 0 P 27 & \\
\hline 101 & Tiftik Van & Kıyye 1 G 10 P 0 & Güm. G 0 P 80 & \\
\hline 102 & Sisam & Kiyye 1 G 1 P 50 & Güm. G 0 P 16 & \\
\hline 103 & Bi'l-cümle kereste & & Rayicinden & \\
\hline 104 & Bi'l-cümle peksimed ve kalyata & & Rayicinden & \\
\hline 105 & $\begin{array}{l}\text { Bamya ve böğrülce ve fasulye ve mer- } \\
\text { cimek ve nohud ve bezelye }\end{array}$ & & Rayicinden & \\
\hline 106 & $\begin{array}{l}\text { Basdırma ve sucuk ve yenâir ve sığır } \\
\text { dili }\end{array}$ & & Rayicinden & \\
\hline 107 & $\begin{array}{l}\text { Onbeş kat yün astare ile dikilmiş aba- } \\
\text { i İslimiye ve zağre a'la }\end{array}$ & Kiyye 1 G 40 P 0 & Güm. G 3 P 20 & \\
\hline 108 & Yedi katlı kazak abası & Kıyye 1 G 26 P 70 & Güm. G 2 P 13 & \\
\hline 109 & Harceli enli şalvarı & Kıyye 1 G 86 P 70 & Güm. G 6 P 93 & \\
\hline 110 & Bayağı şalvar ve yatur & Kiyye 1 G 40 P 0 & Güm. G 3 P 20 & \\
\hline 111 & $\begin{array}{l}\text { Bir ve üç katlı timur koyarak ednâ } \\
\text { 'aba }\end{array}$ & Kiyye 1 G 23 P 30 & Güm. G 1 P 86 & \\
\hline 112 & 'Aba yağmurluk Filibe ve ğare & Kiyye 1 G 73 P 30 & Güm. G 5 P 86 & \\
\hline 113 & $\begin{array}{l}\text { Asker içün Balıkesir ve Pazrcık ve Fi- } \\
\text { libe abası }\end{array}$ & $\begin{array}{l}\text { Tob } 1 \text { Zira' } 11 \\
\text { G } 22 \text { P } 0\end{array}$ & Güm. G 1 P 76 & gori \\
\hline 114 & $\begin{array}{l}\text { Sivari kaba ve kudi-yi yavuz ta'bir olu- } \\
\text { nur 'abâ-i Filibe }\end{array}$ & $\begin{array}{l}\text { Tob } 1 \text { Zira' } 17 \\
\text { karar } 19 \text { G } 43 \text { P } 30\end{array}$ & Güm. G 3 P 46 & $\begin{array}{l}\text { Akademik } \\
\text { Bakış }\end{array}$ \\
\hline 115 & Tiftik ‘abai İslimiye & $\begin{array}{l}\text { Tob } 1 \text { Zira' } 11 \\
\text { G } 53 \text { P } 30\end{array}$ & Güm. G 4 P 26 & $\begin{array}{l}279 \\
\text { Cilt } 10 \\
\text { Say1 } 20\end{array}$ \\
\hline 116 & Beyaz ve siyah ‘aba-i Selanik & $\begin{array}{l}\text { Tob } 1 \text { Zira' } 12 \\
\text { karar } 17 \text { G } 20 \text { P } 0\end{array}$ & Güm. G 2 P 40 & Yaz 2017 \\
\hline 117 & Aba terlik kebir & $\begin{array}{l}\text { Deste } 1 \text { Çift } 10 \\
\text { G } 26 \text { P } 70\end{array}$ & Güm. G 2 P 13 & \\
\hline 118 & Aba terlik sağir & $\begin{array}{l}\text { Deste } 1 \text { Çift } 10 \\
\text { G } 13 \text { P } 30\end{array}$ & Güm. G 1 P 6 & \\
\hline 119 & Tiftik abadan evsat timur koyarak & Kiyye 1 G 33 P 30 & Güm. G 2 P 66 & \\
\hline
\end{tabular}




\begin{tabular}{|c|c|c|c|c|}
\hline & 120 & Aba kaycıni & $\begin{array}{l}\text { Deste } 1 \text { Çift } 10 \\
\text { G } 66 \text { P } 70\end{array}$ & Güm. G 5 P 33 \\
\hline & 121 & Aba üskufe & $\begin{array}{l}\text { Deste } 1 \text { Kiyye } 10 \\
\text { G } 10 \text { P } 0\end{array}$ & Güm. G 0 P 80 \\
\hline & 122 & Kaycınlık aba-i İslimiye & $\begin{array}{l}\text { Parça } 1 \text { Zira' } 3 \\
\text { G } 23 \text { P } 30\end{array}$ & Güm. G 1 P 86 \\
\hline & 123 & Tiftik abadan potur & Kıyye 1 G 46 P 70 & Güm. G 3 P 73 \\
\hline & 124 & Siyah aba-i İslimiye & $\begin{array}{l}\text { Tob } 1 \text { Zira' } 9 \\
\text { Karar } 11 \text { G } 34 \text { P } 70\end{array}$ & Güm. G 2 P 94 \\
\hline & 125 & Nafe ve cilkafa-i Erzurum & Tulum 1 G 150 P 0 & Güm. G 12 P 0 \\
\hline & 126 & Nafe ve cılkafa-i Anadolı & Tulum 1 G 83 P 30 & Güm. G 6 P 66 \\
\hline & 127 & Kasıklı göğsi Anadolı & Çift 1 G 21 P 30 & Güm. G 1 P 70 \\
\hline & 128 & Vaşak Erzurum & Kıyye 1 G 150 P 0 & Güm. G 12 P 0 \\
\hline & 129 & Zerdevâ-i Anadolı ve Rumili & & Rayicinden \\
\hline & 130 & Dilku-yi Anadolı & Kiyye 1 G 8 P 0 & Güm. G 0 P 64 \\
\hline & 131 & Kunduz & Kiyye 1 G 30 P 0 & Güm. G 6 P 40 \\
\hline & 132 & Kurd Anadolı & Tulum 1 G 83 P 30 & Güm. G 6 P 66 \\
\hline & 133 & Çakal Anadolı & Kiyye 1 G 8 P 0 & Güm. G 0 P 64 \\
\hline & 134 & Gücen-i hardesi & Kiyye 1 G 20 P 0 & Güm. G 1 P 60 \\
\hline & 135 & Gücen & & Rayicinden \\
\hline & 136 & Çakal Anadolı & Tulum 1 G 60 P 0 & Güm. G 4 P 80 \\
\hline & 137 & Kedi Anadolı & Tulum 1 G 33 P 30 & Güm. G 2 P 66 \\
\hline & 138 & Kedi pacası Anadolı & Tulum 1 G 36 P 30 & Güm. G 6 P 93 \\
\hline & 139 & Kurd Anadolı & Kiyye 1 G 14 P 70 & Güm. G 1 P 17 \\
\hline & 140 & Sansar Anadolı & Kiyye 1 G 33 P 30 & Güm. G 6 P 66 \\
\hline & 141 & Sarne Anadolı & Tulum 1 G 106 P 70 & Güm. G 8 P 53 \\
\hline gos & 142 & Kuzu-i Rumili & Tulum 1 G 46 P 70 & Güm. G 3 P 73 \\
\hline Akademik & 143 & Cilkafa-i Bosna & Tulum 1 G 266 P 70 & Güm. G 21 P 33 \\
\hline Bakış & 144 & Nafe-i Bosna & Tulum 1 G 240 P 0 & Güm. G 19 P 20 \\
\hline Cilt 10 & 145 & Nafe-i Rumili & Tulum 1 G 166 P 70 & Güm. G 13 P 33 \\
\hline $\begin{array}{r}\text { Sayı } 20 \\
\text { Yaz } 2017\end{array}$ & 146 & Kedi-i Rumili & Tulum 1 G 6 P 30 & Güm. G 0 P 53 \\
\hline & 147 & Cilkafa-i Rumili & Tulum 1 G 233 P 30 & Güm. G 18 P 66 \\
\hline & 148 & Cllkafa-i Ozri & Tulum 1 G 400 P 0 & Güm. G 32 P 0 \\
\hline & 149 & Nafe-i Üsküb & Tulum 1 G 166 P 70 & Güm. G 13 P 33 \\
\hline & 150 & Nafe-i Ozri & Tulum 1 G 300 P 0 & Güm. G 24 P 0 \\
\hline & 151 & Nafe-i Kaluris & Tulum 1 G 100 P 0 & Güm. G 8 P 0 \\
\hline & 152 & Cilkafa-i Bosna Kaluris & Tulum 1 G 166 P 70 & Güm. G 13 P 33 \\
\hline
\end{tabular}




\begin{tabular}{|c|c|c|c|c|}
\hline 153 & Nafe-i Rumili Kaluris & Tulum 1 G 90 P 0 & Güm. G 7 P 20 & \\
\hline 154 & Serne zağre-i Bosna ve Rumili Kaluris & $\begin{array}{l}\text { Deste } 1 \text { Kiyye } 20 \\
\text { G } 46 \text { P } 70\end{array}$ & Güm. G 3 P 73 & \\
\hline 155 & Cilkafa-i Zağre & $\begin{array}{l}\text { Deste } 1 \text { Kiyye } 20 \\
\text { G } 100 \text { P } 0\end{array}$ & Güm. G 8 P 0 & \\
\hline 156 & Dilgü kafası Bosna ve Rumili & Tulum 1 G 266 P 70 & Güm. G 21 P 33 & \\
\hline 157 & Dilgü paçasi & Tulum 1 G 46 P 70 & Güm. G 3 P 73 & \\
\hline 158 & Saz kedisi & Tulum 1 G 46 P 70 & Güm. G 3 P 73 & \\
\hline 159 & Dilgü kafası Rumili evsat & Tulum 1 G 116 P 70 & Güm. G9 P 33 & \\
\hline 160 & Dilgüvi Rumili & Kiyye 1 G 18 P 0 & Güm. G 1 P 44 & \\
\hline 161 & Dilgüvi Bosna & Kiyye 1 G 36 P 70 & Güm. G 2 P 93 & \\
\hline 162 & Boğaz zağre & Çift 1 G 80 P 0 & Güm. G 6 P 40 & \\
\hline 163 & Zerdeva nafesi & & Rayicinden & \\
\hline 164 & Zerdeva paçasi & & Rayicinden & \\
\hline 165 & Zerdeva zardesi & & Rayicinden & \\
\hline 166 & Sansar kafası Rumili & Tulum 1 G 233 P 30 & Güm. G 18 P 66 & \\
\hline 167 & Sansar paçası Rumili & Tulum 1 G 266 P 70 & Güm. G 21 P 33 & \\
\hline 168 & Sansar Rumili & & Rayicinden & \\
\hline 169 & A'la Sansar paçası & & Rayicinden & \\
\hline 170 & Sansar zardesi & Kiyye 1 G 150 P 0 & Güm. G 12 P 0 & \\
\hline 171 & Tüysüz Sansar & Kiyye 1 G 6 P 70 & Güm. G OP 53 & \\
\hline 172 & Gucen pacası & & Rayicinden & \\
\hline 173 & Keçi & Tulum 1 G 14 P 70 & Güm. G 1 P 17 & \\
\hline 174 & Kurd Rumili & Tulum 1 G 76 P 70 & Güm. G 6 P 13 & \\
\hline 175 & Siyah kedi Rumili & Tulum 1 G 183 P 30 & Güm. G 14 P 66 & \\
\hline 176 & Siyah kedi pacası & Tulum 1 G 80 P 0 & Güm. G 6 P 40 & Gori \\
\hline 177 & Vaşak Rumili & & Rayicinden & Akademik \\
\hline 178 & Fare & & Rayicinden & Bakış \\
\hline 179 & Ağır sevâniy-i Haleb & Tob 1 G 295 P 60 & Güm. G 23 P 64 & $\begin{array}{l}281 \\
\text { Cilt } 10\end{array}$ \\
\hline 180 & Evsat sevâni-yi Haleb & Tob 1 G 197 P 10 & Güm. G 15 P 76 & Sayl 20 \\
\hline 181 & Ednâ sevâni-yi Haleb & Tob 1 G 65 P 70 & Güm. G 5 P 65 & \\
\hline 182 & İpekli ketâni-yi Haleb ve Hama & Tob 1 G 29 P 50 & Güm. G 6 P 36 & \\
\hline 183 & Ahen rikâb & Çift 1 G 9P 90 & Güm. G 0 P 79 & \\
\hline 184 & $\begin{array}{l}\text { Başlık ve dizgin ve gem ve kuskun ve } \\
\text { zahme ve kulan }\end{array}$ & $\begin{array}{l}\text { Deste } 1 \text { Kiyye } 1 \\
\text { G } 56 \text { P } 50\end{array}$ & Güm. G 4 P 20 & \\
\hline 185 & Ağaç kalnaf & Kiyye 1 G 4 P 0 & Güm. G 0P 32 & \\
\hline 186 & Kaba gömlek fırniye & Kiyye 1 G 6 P 50 & Güm. G OP 56 & \\
\hline
\end{tabular}




\begin{tabular}{|c|c|c|c|c|}
\hline & 187 & Kilim sâlyinhâne kebir & Kıyye 1 G 49 P 30 & Güm. G 3 P 94 \\
\hline & 188 & Kilim sâlyinhâne sağir & Kiyye 1 G 26 P 30 & Güm. G 2 P 10 \\
\hline & 189 & Asker batâklığı için kilim & Kiyye 1 G 13 P 10 & Güm. G 1 P 4 \\
\hline & 190 & Nuhâsi edâni-yi Tokad & Kiyye 1 G 19 P 30 & Güm. G 1 P 58 \\
\hline & 191 & Nuhâsi edâni-yi Tranzon & Kiyye 1 G 23 P 0 & Güm. G 1 P 84 \\
\hline & 192 & Al döşemelik asram ve yasduka & Kiyye 1 G 39 P 40 & Güm. G 3 P 15 \\
\hline & 193 & Kıyakiye-i zağre & Kiyye 1 G 9 P 90 & Güm. G 0 P 79 \\
\hline & 194 & Keçe-i Selanik & Kiyye 1 G 19 P 70 & Güm. G 1 P 57 \\
\hline & 195 & Hasır sübürgesi & $\begin{array}{l}\text { Arabe } 1 \text { Kiyye } 2000 \text { G } \\
1314 \text { P } 0\end{array}$ & Güm. G 105 P 16 \\
\hline & 196 & Haviye-i karafere & Kiyye 1 G 39 P 40 & Güm. G 3 P 15 \\
\hline & 197 & Peştamal Geyve & Çift 1 G 9 P 90 & Güm. G 0 P 79 \\
\hline & 198 & Meles Berdes & $\begin{array}{l}\text { Top } 41 \text { Kiyye } 22 \\
\text { G } 72 \text { P } 30\end{array}$ & Güm. G 5 P 78 \\
\hline & 199 & Akbaş peştamal Geyve & Çift 1 G 7 P 90 & Güm. G 0 P 63 \\
\hline & 200 & Sade Kolan & Kiyye 1 G 26 P 30 & Güm. G 2 P 10 \\
\hline & 201 & Basma silecek Berdes & Çift 1 G 9 P 90 & Güm. G 0 P 79 \\
\hline & 202 & Çekne Bursa & Top 1 G 65 P 70 & Güm. G 5 P 65 \\
\hline & 203 & Meles Gömlek Bursa & Kıyye 1 G 26 P 30 & Güm. G 6 P 10 \\
\hline & 204 & Eğirme & Kıyye 1 G 78 P 90 & Güm. G 6 P 31 \\
\hline & 205 & Küllah Bursa & Kıyye 1 G 3 P 30 & Güm. G 0 P 26 \\
\hline & 206 & $\begin{array}{l}\text { Nuhâsi-yi evâni Kastamonu ve Kahve } \\
\text { ıbrığ }\end{array}$ & Kiyye 1 G 26 P 30 & Güm. G 6 P 10 \\
\hline & 207 & Cimşir kaşık beyaz ve siyah & Kıyye 1 G 4 P 90 & Güm. G 0 P 39 \\
\hline & 208 & Harfeli ve mercanlı kaşık & $\begin{array}{l}\text { Deste } 1 \text { Kiyye } 10 \\
\text { G } 9 \text { P } 80\end{array}$ & Güm. G 0 P 78 \\
\hline gor & 209 & Ağaç kaşık bi'l-cümle & Kıyye 1 G 2 P 60 & Güm. G 0 P 20 \\
\hline $\begin{array}{r}\text { Akademik } \\
\text { Bakış }\end{array}$ & 210 & Cimşir tarak & $\begin{array}{l}\text { Kaysara } 1 \text { Kiyye } 5500 \\
\text { G } 246 \text { P } 30\end{array}$ & Güm. G 19 P 70 \\
\hline $\begin{array}{c}282 \\
\text { Cilt } 10\end{array}$ & 211 & Ağaç tarak & $\begin{array}{l}\text { Kaysara } 1 \text { Kiyye } 5500 \\
\text { G } 131 \text { P } 40\end{array}$ & Güm. G 10 P 51 \\
\hline Yaz 2017 & 212 & Fincan Kütahya & Küfe 1 G 98 P 50 & Güm. G 7 P 77 \\
\hline & 213 & Güllab & Kıyye 1 G 6P 0 & Güm. G 0 P 16 \\
\hline & 214 & Ağaç Kavi & Kiyye 1 G 26P 30 & Güm. G 6 P 10 \\
\hline & 215 & Mantar Kavi & Kiyye 1 G 6P 50 & Güm. G 0 P 52 \\
\hline & 216 & Tesbih kadesi & Kıyye 1 G 9P 80 & Güm. G 0 P 78 \\
\hline & 217 & $\begin{array}{l}\text { Sepetçi çubuğu ta'bir olunur kârlık ve } \\
\text { çocuk sepeti i'mâl olunur cubuk }\end{array}$ & Arabi 1 G 361 P 30 & Güm. G 28 P 90 \\
\hline
\end{tabular}




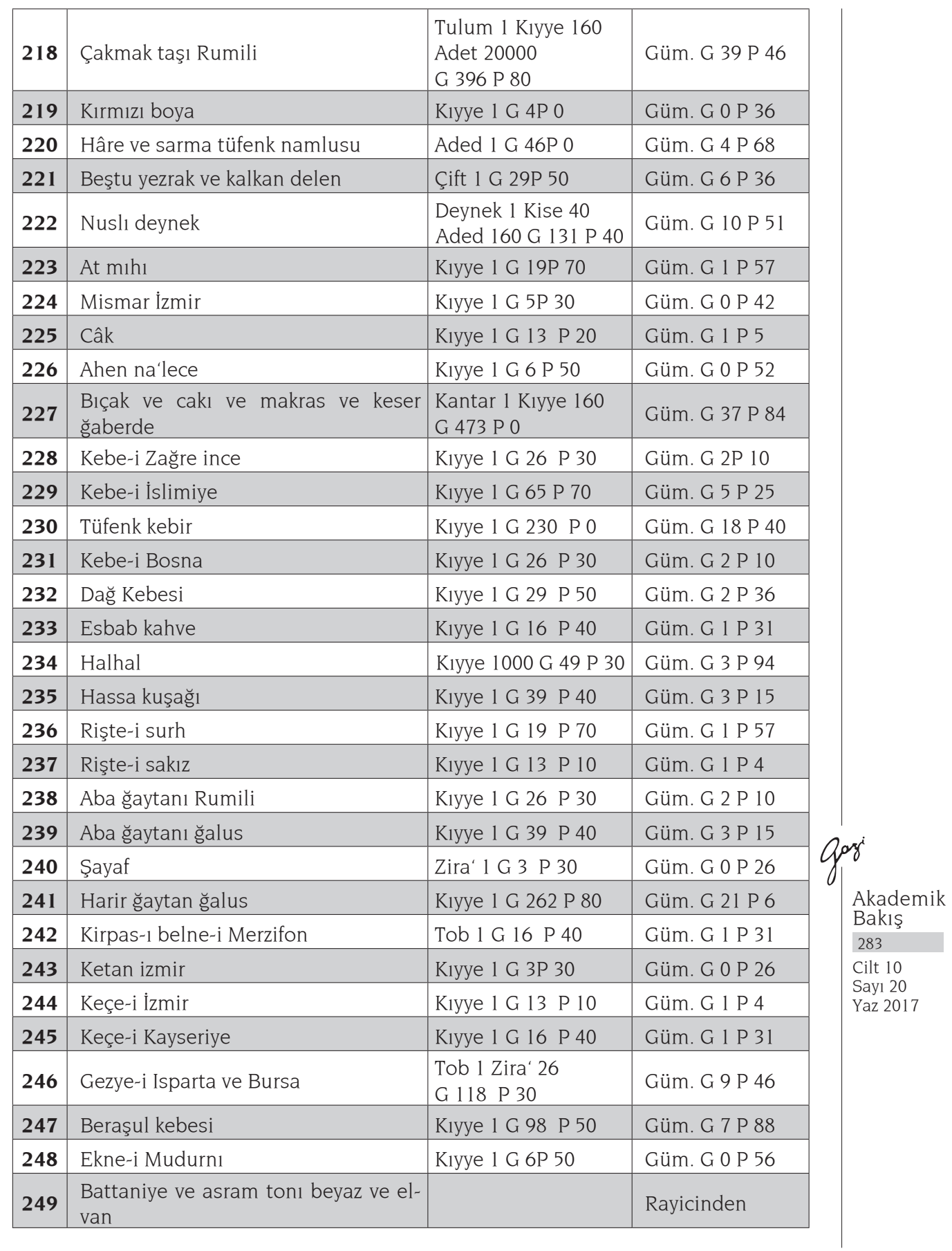




\begin{tabular}{|c|c|c|c|c|}
\hline & 250 & Ayneson Kaysariye & Kıyye 1 G 2P 60 & Güm. G 0 P 20 \\
\hline & 251 & Ayneson Rumili & Kıyye 1 G 2P 30 & Güm. G 0 P 18 \\
\hline & 252 & Istar Kastamonı & $\begin{array}{l}\text { Denk } 1 \text { Tob } 60 \\
\text { G } 450 \text { P } 0\end{array}$ & Güm. G 36 P 0 \\
\hline & 253 & Istar Taşköpri & Kıyye 1 G 3P 90 & Güm. G 0 P 31 \\
\hline & 254 & Istar Hamid & $\begin{array}{l}\text { Denk } 1 \text { Tob } 60 \\
\text { G } 443 \text { P } 50\end{array}$ & Güm. G 25 P 48 \\
\hline & 255 & Bi'l-cümle incir & & Rayicinden \\
\hline & 256 & $\begin{array}{l}\text { Bi'l-cümle benâir ve pekmez ve helva } \\
\text { ve bulaca ve asel ve şem'-i revgan }\end{array}$ & & Rayicinden \\
\hline & 257 & Balık yumurtası & & Rayicinden \\
\hline & 258 & Busta Ankara beyaz ve elvan & & Rayicinden \\
\hline & 259 & Akbaş peştamal Bursa & Çift 1 G 9P 80 & Güm. G 0 P 78 \\
\hline & 260 & Beldiye-i Bursa & Çift 1 G 19 P 90 & Güm. G 1 P 56 \\
\hline & 261 & Beldiye-i Merzifon & Çift 1 G 26 P 10 & Güm. G 2 P 8 \\
\hline & 262 & Peştamal Selanik & Çift 1 G 16 P 30 & Güm. G 1 P 30 \\
\hline & 263 & Ceviz & $\begin{array}{l}\text { Keyl } 1 \text { Kiyye } 100 \\
\text { G } 163 \text { P } 0\end{array}$ & Güm. G 13 P 4 \\
\hline & 264 & Ceriş & Kiyye 1 G 3P 90 & Güm. G 0 P 31 \\
\hline & 265 & Cükün & Kiyye 1 G 1 P 90 & Güm. G 0 P 15 \\
\hline & 266 & Sülük & Kiyye 1 G 195 P 60 & Güm. G 15 P 64 \\
\hline & 267 & Sünger & & Rayicinden \\
\hline & 268 & Halâli şal tevni & Kiyye 1 G 97 P 80 & Güm. G 7 P 86 \\
\hline & 269 & Donluk şal tevni & Kiyye 1 G 52 P 60 & Güm. G 4 P 17 \\
\hline & 270 & Beyaz şal tevni & Kiyye 1 G 26 P 10 & Güm. G 2 P 8 \\
\hline & 271 & Elvan şal tevni & Kiyye 1 G 32 P 60 & Güm. G 2 P 60 \\
\hline Goy & 272 & Şal karacalar & Kiyye 1 G 13 P 0 & Güm. G 1 P 4 \\
\hline Akademik & 273 & Sarırlı şeryab kuşak & Kiyye 1 G 97 P 80 & Güm. G 7 P 82 \\
\hline $\begin{array}{c}\text { Bakış } \\
284 \\
\end{array}$ & 274 & $\begin{array}{l}\text { Müsyab ta'bir olunur nehbi ğarâr ve } \\
\text { kızıl Rum ili ve Anadolı }\end{array}$ & Kiyye 1 G 7 P 80 & Güm. G 0 P 62 \\
\hline Sayı 20 & 275 & Bi'l-cümle zımpar & & Rayicinden \\
\hline Yaz 2017 & 276 & Şali-yi Ankara ve sof enli ve ensiz & $\begin{array}{l}\text { Tob } 1 \text { Zira' } 32 \\
\text { G } 324 \text { P } 0\end{array}$ & Güm. G 33 P 96 \\
\hline & 277 & Beyaz ve elvan asram Rumili & Kiyye 1 G 22 P 50 & Güm. G 1 P 80 \\
\hline & 278 & Bamri kuşak & Kiyye 1 G 77 P 20 & Güm. G 6 P 17 \\
\hline & 279 & İplik şerbab kuşak & Kiyye 1 G 28 P 90 & Güm. G 2 P 31 \\
\hline & 280 & Zagzaran Anadolı ve Rumili & & Rayicinden \\
\hline & 281 & Ruğa don ve çerviş ve sade & & Rayicinden \\
\hline
\end{tabular}




\begin{tabular}{|c|c|c|c|c|}
\hline 282 & $\begin{array}{l}\text { Seccade-i kürsi ve kaliçe-i kürdüs ve } \\
\text { izladi seccade ve seccade-i kula ve } \\
\text { seccade-i saire }\end{array}$ & & Rayicinden & \\
\hline 283 & Şali-yi Tosya ve tüllen kuşak & & Rayicinden & \\
\hline 284 & Sofra ve peşkir samatlı ve sade & Kiyye 1 G 257 P 20 & Güm. G 20 P 57 & \\
\hline 285 & Fota-i Bursa & Çift 1 G 32 P 20 & Güm. G 2 P 57 & \\
\hline 286 & Telli fota-i Hama & Çift 1 G 128 P 60 & Güm. G 10 P 28 & \\
\hline 287 & Bi'l-cümle tuzlu balık & & Rayicinden & \\
\hline 288 & Sanderfe & & Rayicinden & \\
\hline 289 & Kilim Türkman & Kiyye 1 G 128 P 60 & Güm. G 10 P 28 & \\
\hline 290 & Kimyon & Kiyye 1 G 2 P 0 & Güm. G 0 P 16 & \\
\hline 291 & Gülyab & Kiyye 1 G 2 P 0 & Güm. G 0 P 16 & \\
\hline 292 & Kirpas ketan Anadolı & Kiyye 1 G 12 P 80 & Güm. G 1 P 2 & \\
\hline 293 & A'lâ kirpas ketan Rize & Kiyye 1 G 64 P 30 & Güm. G 5 P 14 & \\
\hline 294 & Ednâ kirpas ketan Rize & Kiyye 1 G 25 P 70 & Güm. G 2 P 5 & \\
\hline 295 & Kavsele-i Aydin & Kiyye 1 G 25 P 70 & Güm. G 2 P 5 & \\
\hline 296 & Kavsele-i Gerede & Kiyye 1 G 32 P 20 & Güm. G 2 P 57 & \\
\hline 297 & Ağabâni-yi Bağdad & Kiyye 1 G 24 P 30 & Güm. G 5 P 14 & \\
\hline 298 & Çam sakızı sarı & Kantar 1 G 32 P 20 & Güm. G 2 P 57 & \\
\hline 299 & Çam sakızı beyaz & Kantar 1 G 57 P 80 & Güm. G 4 P 62 & \\
\hline 300 & Kosni & Kiyye 1 G 7 P 70 & Güm. G 0 P 61 & \\
\hline 301 & Sinameki & & Rayicinden & \\
\hline 302 & Kanarya yemi & $\begin{array}{l}\text { Künt-i Asitane } 1 \\
\text { Kiyye } 20 \text { G } 19 \text { P } 30\end{array}$ & Güm. G 1 P 54 & \\
\hline 303 & $\begin{array}{l}\text { Peştumi kavsele-i mande ve kara } \\
\text { sağir }\end{array}$ & Kiyye 1 G 48 P 20 & Güm. G 2 P 85 & nasi \\
\hline 304 & Köfter & Kantar 1 G 160 P 70 & Güm. G 16 P 85 & \\
\hline 305 & Asma kilid Filibe & $\begin{array}{l}\text { Deste } 1 \text { Kiyye } 10 \\
\text { G } 12 \text { P } 80\end{array}$ & Güm. G 1 P 6 & $\begin{array}{l}\text { Akademik } \\
\text { Bakış }\end{array}$ \\
\hline 306 & Gühercile ve lotarden Mısır & & Rayicinden & $\begin{array}{l}285 \\
\text { Cilt } 10\end{array}$ \\
\hline 307 & $\begin{array}{l}\text { Kurı ve tuzlu gön manda ve cild-i ba- } \\
\text { kar sağir ve kebir }\end{array}$ & & Rayicinden & $\begin{array}{l}\text { Say1 } 20 \\
\text { Yaz } 2017\end{array}$ \\
\hline 308 & Erez Misır ve Filibe ve Trabzon & & Rayicinden & \\
\hline 309 & $\begin{array}{l}\text { Memâlik-i marûse-i şâhânede kain } \\
\text { bi'l-cümle maşinlerde hâsıl olan harir }\end{array}$ & Kıyye 1 G 217 P 30 & Güm. G 17 P 38 & \\
\hline 310 & $\begin{array}{l}\text { Memâlik-i marûse-i şâhânede kain } \\
\text { bi'l-cümle manciliklerde hâsıl olan } \\
\text { harir }\end{array}$ & Kiyye 1 G 155 P 0 & Güm. G 12 P 40 & \\
\hline
\end{tabular}




\begin{tabular}{|c|c|c|c|c|}
\hline & 311 & $\begin{array}{l}\text { Kıbrıs ve Aydın ve Menteşe ve Sakız } \\
\text { ve Girid ve Sayfeli ve Haleb ve Beyrut } \\
\text { ve Sayda ve Şam hariri }\end{array}$ & Kiyye 1 G 107 P 50 & Güm. G 8 P 68 \\
\hline & 312 & Kamçı başı & & Rayicinden \\
\hline & 313 & Revga-1 zeyd & Kantar 1 G 140 P 0 & Güm. G 11 P 20 \\
\hline & 314 & Sabun & Kantar 1 G 136 P 50 & Güm. G 10 P 96 \\
\hline & 315 & Asfur Misir & & Rayicinden \\
\hline & 316 & Nuhas köhne & Kiyye 1 G 9 P 30 & Güm. G 0 P 74 \\
\hline & 317 & $\begin{array}{l}\text { Çekre ve ibrahiye ve kütâbi-yi dürzi } \\
\text { dağı }\end{array}$ & $\begin{array}{l}\text { Tob } 1 \text { Zira' } 9 \\
\text { Kadar } 10 \text { G } 41 \text { P } 20\end{array}$ & Güm. G 4 P 29 \\
\hline & 318 & Kendir Kastamonı & Kiyye 1 G 1 P 80 & Güm. G 0 P 14 \\
\hline & 319 & Kendir İzmir & Kiyye 1 G 2 P 40 & Güm. G 0 P 19 \\
\hline & 320 & $\begin{array}{l}\text { Kemerlik ta'bir olunur kirpas } \\
\text { Kastamonı }\end{array}$ & Tob 1 G 5 P 80 & Güm. G 0 P 46 \\
\hline & 321 & Pezmic devan & & Rayicinden \\
\hline & 322 & Varil tahtası & & Rayicinden \\
\hline & 323 & Elvan çarşab Manisa & Tob 1 G 5 P 80 & Güm. G 0 P 46 \\
\hline & 324 & Kirpas Gördes enli ve ensiz & $\begin{array}{l}\text { Denk } 1 \text { Tob } 50 \\
\text { Kadar } 55 \text { G } 411 \text { P } 80 \\
\end{array}$ & Güm. G 32P 94 \\
\hline & 325 & Esvablık kirpas Gördes & Tob 1 G 7 P 0 & Güm. G 0 P 56 \\
\hline & 326 & Bartın necisi & Çift 1 G 14 P 70 & Güm. G 1 P 17 \\
\hline & 327 & Fes boyası & & Rayicinden \\
\hline & 328 & Mor toyraf & Kiyye 1 G 4 P 70 & Güm. G 0 P 37 \\
\hline & 329 & Kebkeb ta'bir olunur kafesçi civiti & & Rayicinden \\
\hline & 330 & Kudret helvası & & Rayicinden \\
\hline & 331 & Ceviz ve tahin helvası & & Rayicinden \\
\hline gor & 332 & Nardenk ve pekmez ve ceviz sucuğl & & Rayicinden \\
\hline Akademik & 333 & Mahleb & Kiyye 1 G 4 P 10 & Güm. G 0 P 32 \\
\hline Bakış & 334 & Al meşin Anadolı ve Rumili & Kiyye 1 G 5 P 30 & Güm. G 0 P 42 \\
\hline Cilt 10 & 335 & Meşin Anadolı ve Rumili & Kiyye 1 G 3 P 20 & Güm. G 0 P 25 \\
\hline $\begin{array}{r}\text { Sayl } 20 \\
\text { Yaz } 2017\end{array}$ & 336 & A'lâ peştu bezrin & & Rayicinden \\
\hline & 337 & Mecer Tosya ve Payas & Tob 1 G 29 P 40 & Güm. G 2 P 25 \\
\hline & 338 & Mursafi & Kiyye 1 G 4 P 70 & Güm. G 0 P 37 \\
\hline & 339 & Kirpas Alaiyye enli & Tob 1 G 5 P 80 & Güm. G 0 P 46 \\
\hline & 340 & Kirpas Alaiyye ensiz & Tob 1 G 4 P 70 & Güm. G OP 37 \\
\hline & 341 & Kirpas Merzifon & Tob 1 G 5 P 80 & Güm. G 0 P 46 \\
\hline & 342 & Istar Kayseriye ve Sivas ve Gülyubi & & Rayicinden \\
\hline
\end{tabular}




\begin{tabular}{|c|c|c|c|c|}
\hline 343 & Aran mustaki & Kıyye 1 G 5 P 80 & Güm. G 0 P 46 & \\
\hline 344 & $\begin{array}{l}\text { Aran Soma ta'bir olunur ceyreden } \\
\text { hasil olan }\end{array}$ & Kıyye 1 G 2 P 90 & Güm. G 0 P 23 & \\
\hline 345 & Hama kuşağı & Kiyye 1 G 15 P 40 & Güm. G 1 P 23 & \\
\hline 346 & Fota-i Bursa & Tob 1 G 83 P 20 & Güm. G 6 P 65 & \\
\hline 347 & Beyaz ve elvan karacalar kuşağı & Kiyye 1 G 10 P 50 & Güm. G 0 P 84 & \\
\hline 348 & Silecik ve havi-yi Bursa kebir ve sağir & Kiyye 1 G 33 P 90 & Güm. G 2 P 71 & \\
\hline 349 & Telli kulak enli ve ensiz & $\begin{array}{l}\text { Deste } 1 \text { Kiyye } 10 \\
\text { G } 58 \text { P } 50\end{array}$ & Güm. G 4 P 68 & \\
\hline 350 & Elvan harir & Kiyye 1 G 246 P 60 & Güm. G 19 P 72 & \\
\hline 351 & Havi-yi Geyve & Kiyye 1 G 24 P 60 & Güm. G 1P 96 & \\
\hline 352 & Zerdeva kafes & & Rayicinden & \\
\hline 353 & Furşom-1 hâm & & Rayicinden & \\
\hline 354 & Kirpas Menemen & Tob 1 G 9 P 20 & Güm. G 0 P 73 & \\
\hline 355 & Misırda hasıl olan eşbatan kafesi & & Rayicinden & \\
\hline 356 & $\begin{array}{l}\text { Kıbrıs âdi şarabı dâhil olduğı halde } \\
\text { bi'l-cümle memalik-i mahrûse şarabı }\end{array}$ & Kıyye 1 G 1 P 80 & Güm. G 0 P 14 & \\
\hline 357 & $\begin{array}{l}\text { Kibrisda hasıl olan Komanderiye } \\
\text { ta'bir olunur şarab }\end{array}$ & & Rayicinden & \\
\hline 358 & Keçe-i Karahisar beyaz ve elvan & Kiyye 1 G 12 P 30 & Güm. G 0 P 98 & \\
\hline 359 & Lüle-i estefe & Sandık 1 G 616 P 40 & Güm. G 49P 31 & \\
\hline 360 & Kendir tohumu & Kiyye 1 G 0 P 80 & Güm. G OP 6 & \\
\hline 361 & Harnub & & Rayicinden & \\
\hline 362 & Istar Geyve & & Rayicinden & \\
\hline 363 & Balık ağı & & Rayicinden & \\
\hline 364 & Hınta Asitane & Keyl 1 G 15 P 30 & Güm. G 1P 22 & \\
\hline 365 & Şa'ir Asitane & Keyl 1 G 5 P 40 & Güm. G 0P 43 & \\
\hline 366 & Kokoroz Asitane & Keyl 1 G 7 P 20 & Güm. G OP 57 & Akademik \\
\hline 367 & Çavdar Asitane & Keyl 1 G 6 P 30 & Güm. G 0P 50 & $\begin{array}{l}\text { Bakış } \\
287\end{array}$ \\
\hline 368 & Alaf Asitane & Keyl 1 G 4 P 10 & Güm. G OP 32 & Cilt 10 \\
\hline 369 & Darı tavuk ve gögercin içün Asitane & Keyl 1 G 4 P 50 & Güm. G OP 36 & $\begin{array}{l}\text { Sayl } 20 \\
\text { Yaz } 2017\end{array}$ \\
\hline 370 & Ketan tohumu Asitane & Keyl 1 G 18 P 0 & Güm. G 1 P 44 & \\
\hline 371 & $\begin{array}{l}\text { Amasyadan mâ'ada bi'l-cümle kuru } \\
\text { koza }\end{array}$ & Kiyye 1 G 74 P 50 & Güm. G 5 P 96 & \\
\hline 372 & Amasyanın koza & & Rayicinden & \\
\hline 373 & Delikli koza & & Rayicinden & \\
\hline 374 & Çifte koza & & Rayicinden & \\
\hline
\end{tabular}




\begin{tabular}{|c|c|c|c|}
\hline 375 & $\begin{array}{l}\text { Dev büyük ve karyizun ta'bir olunur } \\
\text { life }\end{array}$ & & Rayicinden \\
\hline 376 & Bi'l-cümle harir tohumu & Kıyye 1 G 450 P 0 & Güm. G 36 P 0 \\
\hline 377 & Günlük & & Rayicinden \\
\hline 378 & Meyan balı & & Rayicinden \\
\hline 379 & $\begin{array}{l}\text { Yapağı Anadulı ve Rumili ve } \\
\text { Dersa'detin yıkanmış gürceli ve kirli } \\
\text { yapağı }\end{array}$ & Kantar 1 G 192 P 0 & Güm. G 15 P 36 \\
\hline 380 & $\begin{array}{l}\text { Yapağı Anadolı ve Rumili ve } \\
\text { Desa'adetin yıkanmış yapağı }\end{array}$ & Kantar 1 G 234 P 0 & Güm. G 18 P 72 \\
\hline \multirow[t]{2}{*}{381} & Nuhas külçe & & Rayicinden \\
\hline & Beryetü'ş-şam ve Trablusğarb ve Bağc & dad ve ol havalilerde 1 & asula gelen yapağ \\
\hline 382 & Yıkanmamış ve gürceli & Kantar 1 G 134 P 50 & Güm. G 10 P 76 \\
\hline 383 & Yıkanmış & Kantar 1 G 134 P 50 & Güm. G 13 P 12 \\
\hline
\end{tabular}

\section{Asitane Mahsûlâtı}

\begin{tabular}{|c|c|c|c|}
\hline & ÜRÜN CINSİ & KIYMETI & GÜM. MÍKTARI \\
\hline 1 & Şali-yi Asitane & $\begin{array}{l}\text { Tob } 1 \text { Zira' } 27 \\
\text { G } 178 \text { P } 70\end{array}$ & Güm. G 14 P 29 \\
\hline 2 & Bindallı & Tob 1 G 99 P 30 & Güm. G 7 P 94 \\
\hline 3 & Nuhfahâne & Tob 1 G 56 P 30 & Güm. G 7 P 94 \\
\hline 4 & Cenari Asitane ve fotani ve hegbe & Tob 1 G 66 P 20 & Güm. G 5 P 29 \\
\hline 5 & Alaca-i Vefa a'lâ & $\begin{array}{l}\text { Tob } 1 \text { Zira' } 9 \\
\text { Kadar } 10 \text { G } 33 \text { P } 10\end{array}$ & Güm. G 2 P 64 \\
\hline 6 & Alaca-i Vefa ednâ & $\begin{array}{l}\text { Tob } 1 \text { Zira' } 9 \\
\text { Kadar } 10 \text { G } 16 \text { P } 50\end{array}$ & Güm. G 1 P 32 \\
\hline 7 & Halat marka 'âdi & Kiyye 1 G 19 P 80 & Güm. G 1 P 58 \\
\hline 8 & Sağir halat marka & Kıyye 1 G 9 P 90 & Güm. G 0 P 79 \\
\hline 9 & Mulsi ve bermecik Asitane & Tob 1 G 66 P 20 & Güm. G 5 P 29 \\
\hline 10 & Çit Asitane & Tob 1 G 16 P 50 & Güm. G 1 P 32 \\
\hline 11 & Cehde bermecil & Kiyye 1 G 26 P 50 & Güm. G 2 P 12 \\
\hline 12 & Peten & Tob 1 G 198 P 50 & Güm. G 15 P 88 \\
\hline 13 & Altun baş taklidi kazib teryan & Kiyye 1 G 26 P 50 & Güm. G 2 P 12 \\
\hline 14 & Ednâ kazib teryan & Kiyye 1 G 13 P 30 & Güm. G 1 P 6 \\
\hline 15 & Nuhasi leğen ıbrık & Kiyye 1 G 82 P 70 & Güm. G 6 P 61 \\
\hline 16 & Nuhasi evâni-yi Asitane & Kiyye 1 G 26 P 50 & Güm. G 2 P 12 \\
\hline 17 & Tunç evâni & Kiyye 1 G 23 P 20 & Güm. G 1 P 85 \\
\hline 18 & Kazib işleme hâvi & Kiyye 1 G 6 P 60 & Güm. G 1 P 52 \\
\hline
\end{tabular}




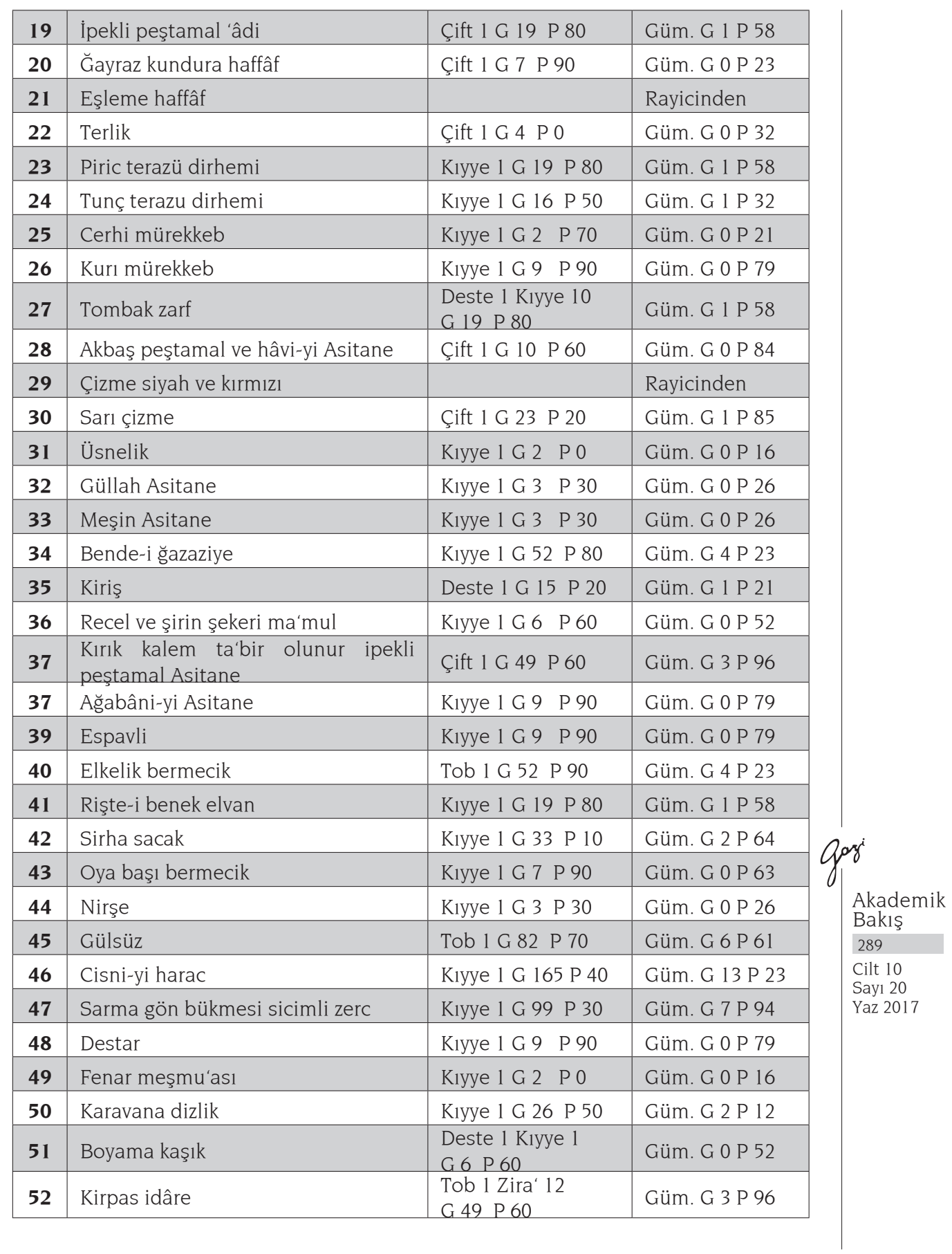




\begin{tabular}{|c|c|c|c|c|}
\hline & 53 & Kirpas Yanya & $\begin{array}{l}\text { Tob } 1 \text { Zira' } 12 \\
\text { G } 13 \text { P } 30\end{array}$ & Güm. G 1 P 6 \\
\hline & 54 & Kirpas Yanya gömlek & Kıyye 1 G 9 P 90 & Güm. G 0 P 79 \\
\hline & 55 & Kirpas Yanya don & Kiyye 1 G 6 P 60 & Güm. G 0 P 56 \\
\hline & 56 & Kazib haşem & $\begin{array}{l}\text { Kiyye } 1000 \text { G } 66 \text { P } \\
20\end{array}$ & Güm. G 5 P 29 \\
\hline & 57 & Meles gömlek & Kiyye 1 G 29 P 0 & Güm. G 2 P 38 \\
\hline & 58 & Meles don & Kiyye 1 G 23 P 20 & Güm. G 1 P 85 \\
\hline & 59 & Marpic & Deste 1 G 59 P 60 & Güm. G 4 P 76 \\
\hline & 60 & Müsta'mel nuhas & Kiyye 1 G 16 P 50 & Güm. G 1 P 32 \\
\hline & 61 & Cerhi na'lebe & Çift 1 G 2 P 70 & Güm. G 0 P 21 \\
\hline & 62 & Yorgan yüzi ve basma silecek & Kiyye 1 G 6 P 60 & Güm. G 0 P 52 \\
\hline & 63 & Yün harc & Kiyye 1 G 49 P 60 & Güm. G 3 P 96 \\
\hline & 64 & Yular & Deste 1 G 16 P 50 & Güm. G 1 P 32 \\
\hline & 65 & Filidan Asitane & Miskâl l G 4 P 30 & Güm. G 0 P 24 \\
\hline & 66 & Altun varak Asitane & Tefe 1 G 92 P 50 & Güm. G 7 P 40 \\
\hline & 67 & Davluk kavsele-i Asitane & Kiyye 1 G 30 P 80 & Güm. G 2 P 46 \\
\hline & 68 & Kazali enek Asitane & Kiyye 1 G 24 P 70 & Güm. G 1 P 97 \\
\hline & 69 & Şerbet Asitane & & Rayicinden \\
\hline & 70 & Kebir a'lâ kalemkâr yemeni Asitane & Kiyye 1 G 6 P 20 & Güm. G 0 P 49 \\
\hline & 71 & Vasat kalemkâr yemeni & Kiyye 1 G 4 P 60 & Güm. G 0 P 36 \\
\hline & 72 & Sağir ve ednâ kalemkâr yemeni & Kıyye 1 G 1 P 50 & Güm. G 0 P 12 \\
\hline & 73 & Fildişi tarak Asitane & Kiyye 1 G 123 P 30 & Güm. G 9 P 86 \\
\hline & 74 & Sarma ve sim tel Asitane & & Rayicinden \\
\hline & 75 & Harir Ğaraziyye-i Asitane & Kiyye 1 G 308 P 20 & Güm. G 24 P 65 \\
\hline Opy & 76 & Basma Hassa & $\begin{array}{l}\text { Tob } 1 \text { Degirmi } 20 \\
\text { G } 12 \text { P } 30\end{array}$ & Güm. G 0 P 98 \\
\hline Akademik & 77 & Üsküdar yimenisi & Tob 1 G 27 P 80 & Güm. G 2 P 22 \\
\hline $\begin{array}{c}\text { Bakış } \\
290 \\
\text { Cilt } 10 \\
\text { Sayı } 20\end{array}$ & $\begin{array}{l}\text { Kom } \\
\text { Züin }\end{array}$ & $\begin{array}{l}\text { isyon reisi devletlui İsmail Paşa } \\
\text { asrâyin ta'bir olunur Cermanya' }\end{array}$ & $\begin{array}{l}\text { retlerine vekâlet } A \\
\text { memâlik-i münfik }\end{array}$ & $\begin{array}{l}\text { Asâlete } \\
\text { ası mahsûlâtı }\end{array}$ \\
\hline Yaz 2017 & & ÜRÜN CINSİ & KIYMETI & GÜM. MİKTARI \\
\hline & 1 & İğne-i ednâ & $\begin{array}{l}\text { Püset } 1 \text { Aded } 50.000 \\
\text { G } 186 \text { P } 90\end{array}$ & Güm. G 14 P 95 \\
\hline & 2 & İğne-i evsat ve a'lâ & & Rayicinden \\
\hline & 3 & Esfarac & Kantar 1 G 153 P 50 & Güm. G 12 P 28 \\
\hline & 4 & Bi'l-cümle eldivan & & Rayicinden \\
\hline & 5 & Bi'l-cümle ustura & & Rayicinden \\
\hline
\end{tabular}




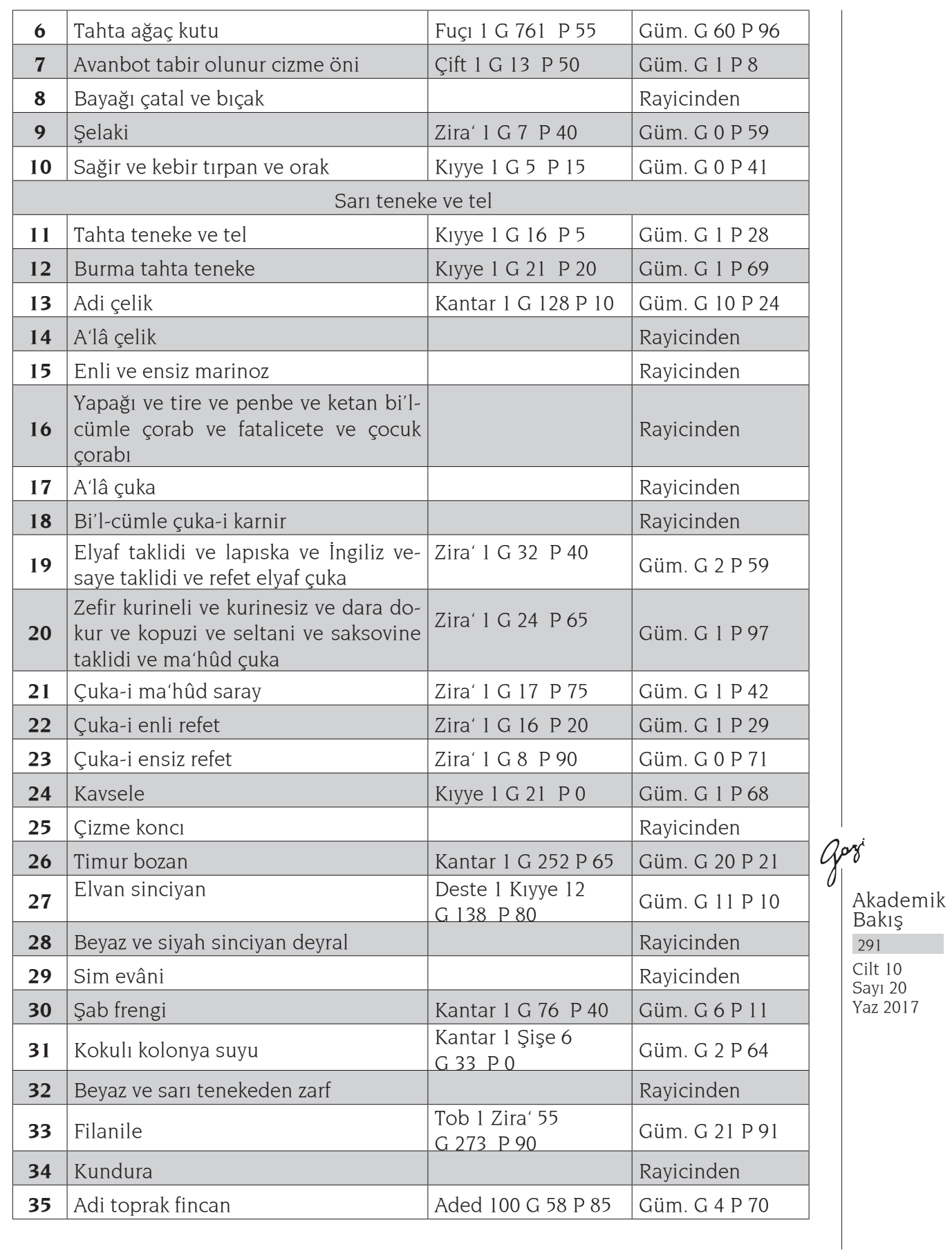




\begin{tabular}{|c|c|c|c|c|}
\hline & 36 & Aynalı teneke kutu & $\begin{array}{l}\text { Deste } 1 \text { Aded } 12 \\
\text { G } 4 \text { P } 85\end{array}$ & Güm. G 0 P 38 \\
\hline & 37 & Kağıd la'ib & $\begin{array}{l}\text { Deste } 1 \text { Takım } 12 \\
\text { G } 16 \text { P } 85\end{array}$ & Güm. G 1 P 34 \\
\hline & 38 & Bi'l-cümle kağıd posta & & Rayicinden \\
\hline & 39 & Güher barham & Kantar 1 G 1215 P 0 & Güm. G 97 P 20 \\
\hline & 40 & Sarcı mum makarası & $\begin{array}{l}\text { Deste } 5 \text { Aded } 60 \\
\text { G } 58 \text { P } 70\end{array}$ & Güm. G 4 P 69 \\
\hline & 41 & Kula ta'bir olunur bir nev' nişasta & Kiyye 1 G 4 P 35 & Güm. G 0 P 34 \\
\hline & 42 & Sarı teneke ve timur ve kurşun yüksek & & Rayicinden \\
\hline & 43 & Al rişte & Kiyye 1 G 30 P 0 & Güm. G 2 P 40 \\
\hline & 44 & Kild nuhas ve pirinçden & Aded 100 G 152 P 20 & Güm. G 12 P 17 \\
\hline & 45 & Arak pelvan ipsened ta'bir olunur & & Rayicinden \\
\hline & 46 & Yeşimden ma'mul hırdavat & & Rayicinden \\
\hline & 47 & Bi'l-cümle timur sarf & & Rayicinden \\
\hline & 48 & Bi'l-cümle kurdaliye & & Rayicinden \\
\hline & 49 & Bi'l-cümle furça & & Rayicinden \\
\hline & 50 & Kehribardan ma'mul tesbih ve sa'ir & & Rayicinden \\
\hline & 51 & Tenkar & & Rayicinden \\
\hline & 52 & Çivdic ta'bir olunur perdesiya maisi & & Rayicinden \\
\hline & 53 & Arak & Kıyye 1 G 4 P 70 & Güm. G 0 P 38 \\
\hline & 54 & Arpa suyu fiçu ile gelen & Kiyye 1 G 3 P 30 & Güm. G 0 P 26 \\
\hline & 55 & Ruğan sade & Kiyye 1 G 16 P 40 & Güm. G 1 P 31 \\
\hline & 56 & Kitab basma için kağıd & & Rayicinden \\
\hline & 57 & Kağıd eyeri & & Rayicinden \\
\hline 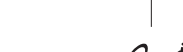 & 58 & Kurşun kalem & & Rayicinden \\
\hline Gor & 59 & Basma kitab & & Rayicinden \\
\hline Akademik & 60 & Kulaklı ve kulaksız bi'l-cümle günlük & & Rayicinden \\
\hline $\begin{array}{c}\text { Bakış } \\
292\end{array}$ & 61 & $\begin{array}{l}\text { Altun ve sim ve elmas kuyumcu } \\
\text { ma'mulatı eşya }\end{array}$ & & Rayicinden \\
\hline $\begin{array}{r}\text { Cilt } 10 \\
\text { Say1 } 20\end{array}$ & 62 & Bi'l-cümle şerit & & Rayicinden \\
\hline Yaz 2017 & 63 & Çikolata & & Rayicinden \\
\hline & 64 & Kanakana & & Rayicinden \\
\hline & 65 & Hamr şanpanya & Bevkal 1 G 13 P 40 & Güm. G 1 P 7 \\
\hline & 66 & Timur tel & & Rayicinden \\
\hline & 67 & Bakır tel & Kiyye 1 G 27 P 0 & Güm. G 2 P 16 \\
\hline & 68 & $\begin{array}{l}\text { Manğır büyük ve küçük a'lâ ve ednâ } \\
\text { bi'l-cümle }\end{array}$ & Kıyye 1 G 49 P 10 & Güm. G 4 P 92 \\
\hline
\end{tabular}




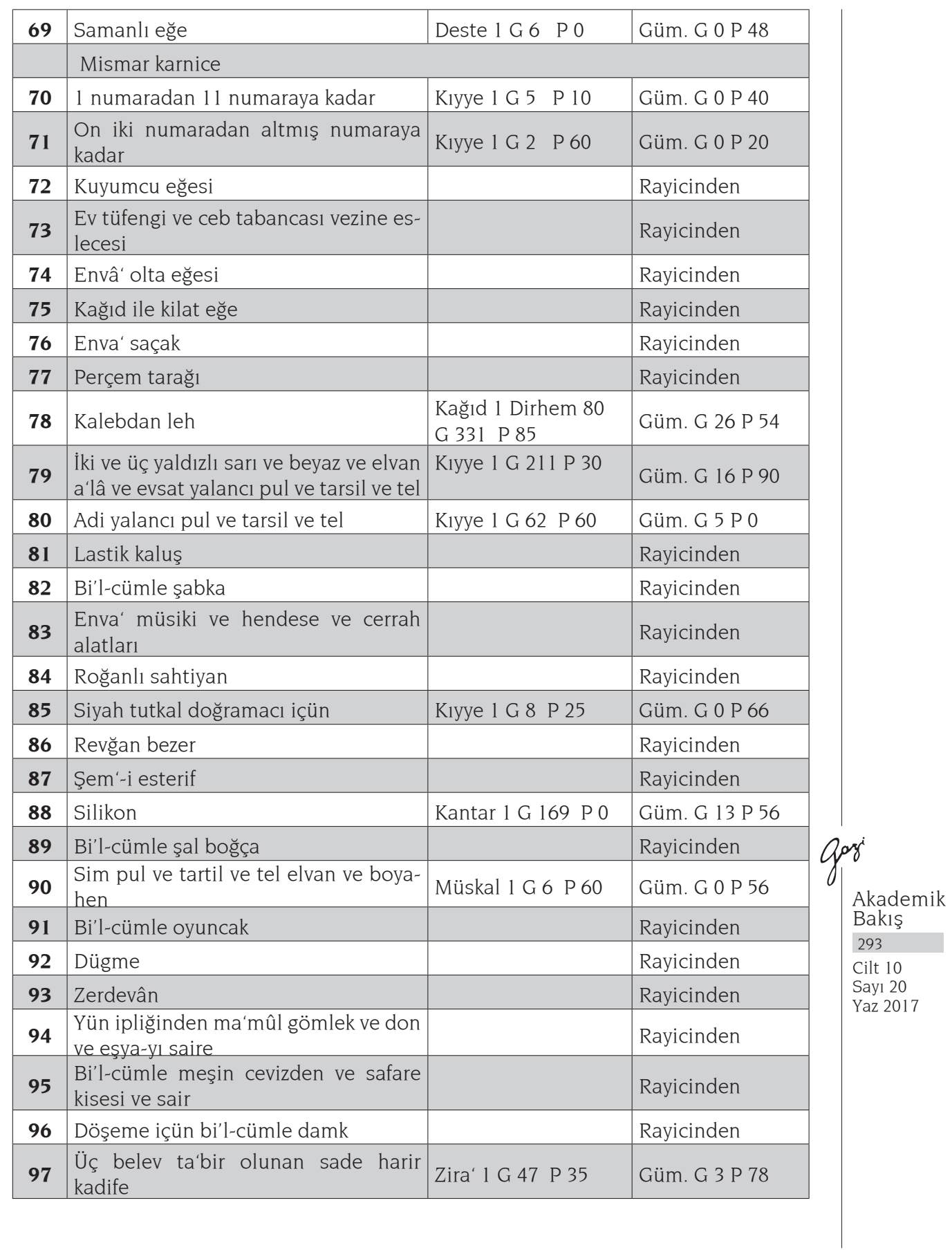




\begin{tabular}{|c|c|c|c|c|}
\hline \multicolumn{5}{|c|}{\begin{tabular}{l|l}
$n$ & Zira \\
it
\end{tabular}} \\
\hline & 99 & Pamuk kadife & Mesared 1 G 3 P 95 & $\begin{array}{l}\text { Güm. G } 0 \text { P } 31 \\
\text { Eni } 24 \text { inçden } 26 \\
\text { inçe kadar }\end{array}$ \\
\hline & 100 & Yamuk kadife & Mesared 1 G 3 P 50 & $\begin{array}{l}\text { Güm. G } 0 \text { P } 28 \\
\text { Eni onbeş inçden } \\
\text { on yedi inceye ka- } \\
\text { dar }\end{array}$ \\
\hline & 101 & Al debsa yamuk kadife & & Rayicinden \\
\hline & 102 & Düz canfes ve atlas ve levantin ve serçi & Zira' 1 G 10 P 70 & $\begin{array}{l}\text { Güm. G } 0 \text { P } 85 \\
\text { Eni altı rubu'dan } \\
\text { bir endâzeye ka- } \\
\text { dar }\end{array}$ \\
\hline & 103 & $\begin{array}{l}\text { Sade canfes ve atlas ve levantin ve } \\
\text { serçi }\end{array}$ & Zira' 1 G 21 P 30 & $\begin{array}{l}\text { Güm. G } 1 \text { P } 70 \\
\text { Eni bir buçukdan } \\
\text { iki endâzeye ka- } \\
\text { dar }\end{array}$ \\
\hline & 104 & $\begin{array}{l}\text { Eni bir buçuk endazeden aşağı ve bir } \\
\text { endazeden yukarı olan dever ya'ni } \\
\text { sade ve çiçeksiz canfes ve atlas ve le- } \\
\text { vantin ve serçi }\end{array}$ & Zira' 1 G 15 P 80 & Güm. G 1 P 26 \\
\hline & 105 & Ak füraze ta'bir olunan çiçeli canfes & Zira' 1 G 11 P 85 & $\begin{array}{l}\text { Güm. G } 0 \text { P } 94 \\
\text { Eni altı rubu'dan } \\
\text { bir endazeye ka- } \\
\text { dar }\end{array}$ \\
\hline & 106 & $\begin{array}{l}\text { Ğarvedir napalı ta'bir olunur bi'l-cüm- } \\
\text { le harirden deymi dokuması }\end{array}$ & & Rayicinden \\
\hline & 107 & Şeker kelle & Kantar 1 G 260 P 50 & Güm. G 20 P 84 \\
\hline & 108 & Şeker ğabar pirime ve dökme ve esmer & Kantar 1 G 209 P 65 & Güm. G 16 P 74 \\
\hline gori & 109 & $\begin{array}{l}\text { Şeker hâm siyah ve sarı muskuhede } \\
\text { ta'bir olur }\end{array}$ & Kantar 1 G 165 P 80 & Güm. G 13 P 26 \\
\hline Akademik & 110 & Çakı ve bıçak ve makras & & Rayicinden \\
\hline $\begin{array}{c}\text { Bakiş } \\
294 \\
\text { Cilt } 10\end{array}$ & 111 & $\begin{array}{l}\text { Dülger ve doğramacı ve kuyumcı ve } \\
\text { tenekeci ve sair alâtları }\end{array}$ & & Rayicinden \\
\hline Say1 20 & 112 & Hamr rino & & Rayicinden \\
\hline & 113 & Enva' batfon ma'deni & & Rayicinden \\
\hline & 114 & Hâm sencab & Kıyye 1000 G 1659 P 0 & Güm. G 132 P 72 \\
\hline & 115 & Sir secab siyah hâm & Kıyye 1000 G 3185 P 85 & Güm. G 254 P 86 \\
\hline & 116 & Secab terbiye olunmuş & $\begin{array}{l}\text { Deste } 1 \text { Kiyye } 10 \\
\text { G } 31 \text { P } 85\end{array}$ & Güm. G 2 P 54 \\
\hline & 117 & Lazkiye & $\begin{array}{l}\text { Sorak } 1 \text { Kiyye } 40 \\
\text { G } 111 \text { P } 50\end{array}$ & Güm. G 8 P 1692 \\
\hline
\end{tabular}




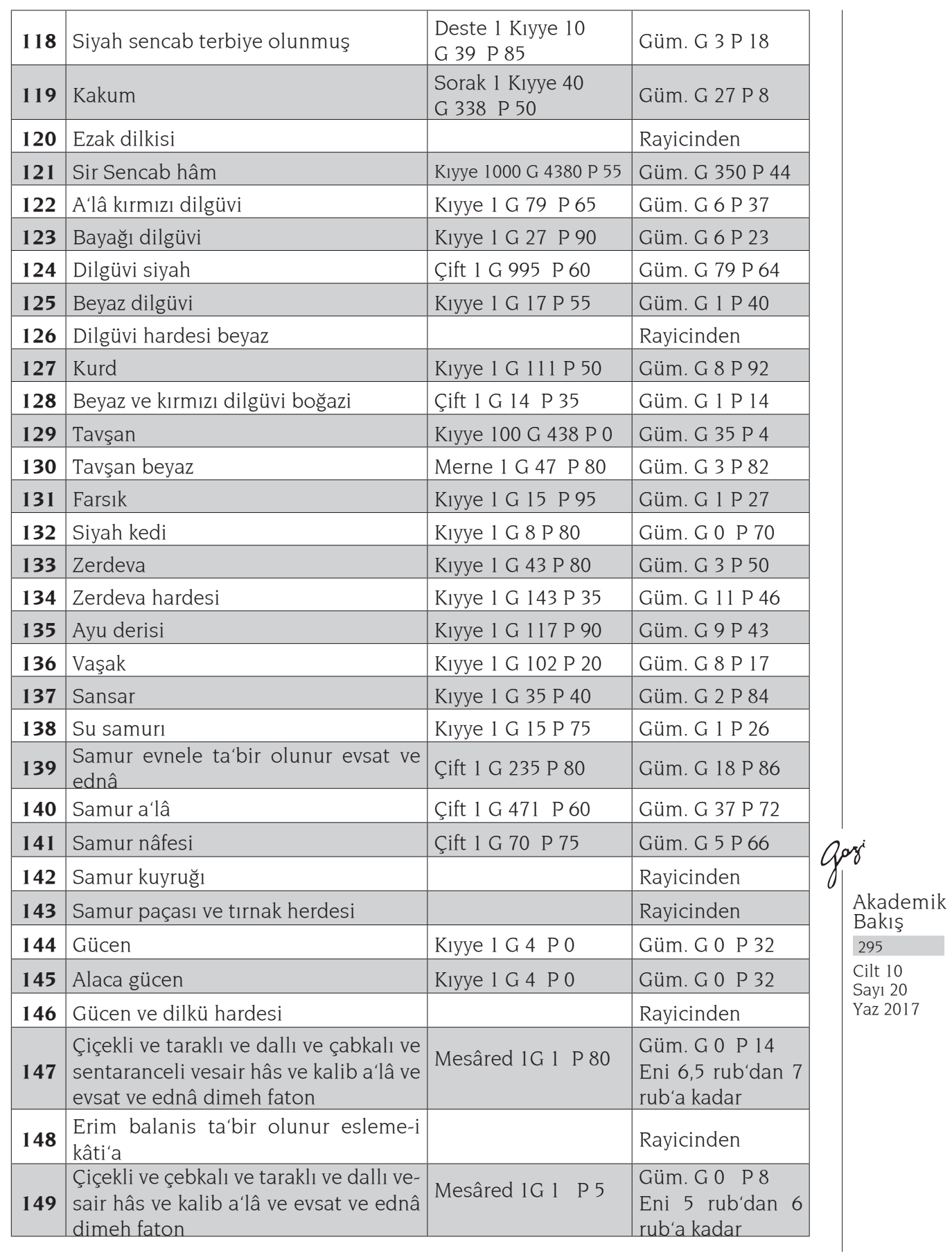


zü-nasrâyin tüccarının ber-vechi bâlâ ğayr-1 ez memnû'ât memalik-i şâhâneye getürdikleri ve ondan alıb götürdükleri kâffe-i emti‘a ve eşyanın ahz olacak resm gümriği ber mûceb mu'ahede-i cedide yüzde sekiz olarak ta'yin kılınmış ve alınacak resm-i Güm. zikr olunan mu'ahede-i cedide iktizasınca iskele kıymetlerinden olması meşrût bulunmuş oldığından işbu ta'rifede tüccâr-1 merkûmenin külliyet üzere alub satdıkları fiyatlar üzerine yüzlük mecidiye altunı yüz guruşa iğtibariyle tahkîk olunan kıymetlerini iskele kıymetlerine indirmek içün yüzde onu tenzil olunduktan sonra sâfi klymetleri üzerinden resm Güm. leri ta'yin ve ta'rif olunmağla ol vechle ahz ve tahsîl olunacakdır ihrâcat içün yüzde sekiz hesâbıyla gösterilmiş olan resm-i Güm. ta'rife-i mezkûrenin yalnız birinci senesi hakkında olduğından ikinci sene ibtidâsında bundan bir semen tenziliyle yüzde yedi ve üçüncü sene kezâlik bir seb' tenziliyle yüzde altıya indirilerek ya'ni bu hesâb üzere resm-i mezkûr sekizinci senede yüzde bire ininceye değin her sene yüzde biri tenzîl idilerek ona göre istihsâl kılınub sekizinci sene ile ondan sonra gelecek senelerde yalnız yüzde bir hesâbıyla ve Güm. masrafı mukâbilinde olarak ahz kılınması mu'ahede-i cedide iktizasından olmağla Güm. lerde bu vechle icrâ kılınacaktır ta'rifede ismi mevcûd ve mukayyed olmayan veyahûd ismi mukayyed oluviren behâsı ta'yin olunmayarak râyice bırağılmış olan emti'a ve eşya râyic ve kıymetine göre bi'l-hesâb ihrâcatdan ise ber-vechi muharrer râyic vakt üzere kıymetinden yüzde onu tenzîl olunduktan sonra giriye kalacak behâsından eşya-yı ma'rifede olacağı gibi hersene yüzde biri tenzîliyle resm-i Güm. alınacakdır ve Zü-Nasârin memâliki mahsûlâtından olarak memalik-i mahrûseye idhâl olunan emti'a ve eşyadan mütemadiyen yüzde sekiz alınub eğer ma'ruf olmayan veyahûd ta'rifede râyice bırağılan eşya gelür ise kezâlik kıymetinden yüzde on tenzîliyle yüzde dâima sekiz alacakdır ve işbu idhâlat ve ihrâcatdan alınacak resm-i Güm. heyet-i mîriye üzere altun ve gümüş meskûkât-ı hâlisa olarak tahsîl olunub resm-i mezkûre içün virilecek yüzlük mecidiye altunı yüz $G$ hesâbıyla ve bunun aksamı olan altun ve gümüş meskûkât-1 hâlisa ona göre ve beş aded gümüş mecidiye bir altun mecidiyeye bedelle yüz G iğtibâriyle ve meskûkât-1 ecnebiye bu tesbit üzere darb-hâne fiyatı vechle peşinen ahz olunacakdır der-saâdetde tüccâr altun mecidiyye yine yüz $\mathrm{G}$ hesabıyla olmak üzere mezkûr mecidiye altunı yerine borsada en ziyâde yüksek fiyatı üzerine kâime-i nakdiye virmek isterlerse câiz olacağından bunun içün bir gün evvel borsada mecidiye altunı kâime igtibâriyle her kaç guruşa idiyse beher gün borsadan celeb ile Güm. de alametü'n-nâs ta'lik kılınacak borsa pusulasından münderiç olan en yüksek fiyatı hesabıyla bir mecidiye altunı bedeline kaç guruşlık kâime-i nakdiye virmeleri lâzım gelür ise ol hesâb üzere kâime-i mezkûre dahi kabul kılınacakdır ve bu vechle meskûkân-1 hâlide yerine mecidiye altunı yüz G hesabıyla kâime-i nakdiyenin kabuli şimdiki halde yalnız Der-sa'adete mahsus münhasır olacaktır ve amma taşralarda dahi kaime-i nakdiye tedâvül idecek oldığı halde ora Güm. lerinde dahi enfâi Der-saâdet Güm. leri hakkında zikri geçdiği misüllü yüzlük mecidiye altunı bedeline her 
kaç guruşluk kâime virilmek lazım gelir ise ol hesâb üzere kâime-i mezkûre kabûl olunacak ise de bunun suret-i nâidiyesi hakkında şimdiden bâkî kable'lvukû' meçhul üzere bir kâidenin vaz‘ ve ta‘yini mümkün olmayacağından taşra Güm. leri hakkında işbu kaimenin suret-i te'diyesi me'elesi şimdilik mevkûf bırağılarak icâb ider ise ba'de mâ görinecek usûl üzerine Bâb-1 'âlî ile devlet-i meşâr-1 ileyhâ sefâranı arasında iktizasına bakılacak ve ol vakte kadar taşra Güm. lerinde resm-i Güm. bâlâda beyânı sebkat itdiği vechle yüzlük mecidiye altunı yüz $G$ hesabıyla ve bunun aksâmı olan altun ve gümüş meskûkât-1 hâssa ona göre ve beş aded gümüş mecidiye bir altun mecidiye bedeline yüz G i'tibârıyla ve meskûkât-1 ecnebiye bu nisbet üzere olan darbhâne fiyatı vechle ahz kılınacakdır ve ber vech-i muharrer ta'rifede olmayan emti'nın cen-i zuhurunda ve gerek ta'rifede râyic klymetinden resm-i Güm. alınmak üzere mukayyed olan emti'a ve eşya hakkında fiyatı takdirinden dolayı Güm. me'mûrlarıyla tüccâr beyânında uyuşuyla meyubede münâzi'a zuhûr eylediği halde usûl-i kâimesi üzere rem-i gümrügi aynen virilüb alınacakdır ve bin ikiyüz seksenbeş senesinde vâki' olacak Martın sekizinci ve bin sekizyüz altmış dokuz senesi alafıranga Martın yirminci gününe kadar gerek Der-sa'âdet gümriği ve gerek memalik-i mahrûse de kâin bi'l-cümle Güm. lerde hükmi cârî olmak ve müddet-i mezkûrenin inkizâsından bir sene evvel yani en sonraki sene zarfında ahad tarafeyn ta'rifenin ta'dîl ve tecdidini taleb itmeğe istihkâfı bulunmak ve müddet-i mezkûreyi bir sene murûr idüvire canibinden biri tecdîd ta'rifeyi istid'â itmediği halde müddeti yedi sene dahâ muhted olmak üzere Devlet-i 'aliyye ile sefâret-i müşâr ileyhâ beyninde virilen karar resmî ve olbabda müte‘allik buyrulan irâde-i seniyye mucebince işbu defter tanzâm ve terkâm ve imzâ olunmuşdur.

19 Ramazan sene 1278

Komisyon Reisi Devletliu İsmail Paşa Hazretlerine

\section{Extended Abstract}

Vekâlet

Europe XIX. century, the political, economic and military aspects of the deep and lasting traces of the developments were left as possible. Indeed, it is observed that these developments, which will deeply affect Europe, are the French-British economic competition and the resulting French Revolution in relation to America. After the Revolution, the Prussian State generally preferred to be in a state of monitoring developments.

Germany Chancellor Bismarck has given priority to ensuring the continuation of European peace. Because the majority of the reasons that force Bismarck to do so draw attention. First of all, this will be the result of France's expansionist initiatives in Europe. The German-French war of 1870-1871, which

Akademik Bakış 297 Cilt 10 Say1 20 Yaz 2017 
started with the resistance of Germany against France, emerged as a factor which forced the German Chancellor Bismarck to be a very difficult factor. German-Russian tension will be added to this. Another effective cause seems to be the struggles between Protestant-Catholic sects in Germany.

XVII. until the middle of the 19th century, the Ottoman Empire was in general regulated by tradesmen of other state traders through aids. According to this, the trade tax that foreign merchants should pay was taken as "mutadus rusum", which is specified only in "customs and law" without specifying the rate. The Ottoman Empire practiced this practice not on the basis of 2\% to 5\% applied during the period of other Turkish states before it, but on the basis of its own principles, based on the trade taxes given by the subject merchant. This rate has been between $2 \%$ and $9 \%$ for imports of foreign government crop products and between $4 \%$ and $9 \%$ for exports. In the Ottoman Empire, the products which were taken from the foreign states or transferred from one place to another by land and sea were taxed according to the sherry and customary law. These taxes are; Often in irregular ways, in port, in city and town entrances, in municipalities in different ways such as municipality, refti, mururie, bâc, specialty, canteen, licensee, canteen, in some places in cargo and equivalent and in some places in value.

XIX. when it comes to the second half of the century, the Ottoman State will be struggling against European economic states with economic economic policies. As a result of this, the Ottoman State will go to renew the trade agreements it has made with "permissive states". The trade agreement signed with Germany in 1862 is a reflection of this struggle. Customs tariff books will be renewed with Germany as well as with other states. This renewed tariff book also reflects the change in the Ottoman state's cadastral economic understanding. The fact that Babylon tries to do it is in fact an effort to pass on to the understanding of customs. Because of the 608 items in the tariff book, the dropping of 130 persons is a sign of this. It is understood that the idea of eliminating the disputes in the calculation of the value which is the basis of the product's customs tax is primarily effective in releasing the products. On the other hand,

Bakıs to reduce the damage of the treasure from the ups and downs of the product price, it is desired to leave the products in a raft and to get the customs tax on the current values.

The tariff book starts with the expression "zü-nasrâyin ta'bir olunur Cermanya". After listing the reasons for preparing this book, three separate lists were prepared. In the first list, the Ottoman State crops, goods, assets and customs tax amounts, which are referred to as "Memalik-i Mahrûsa-i Şahane Mahsûlâtı", will be purchased by the Cermany merchant. It is thought that the expression "Memalik-i Mahrûsa-i Şahane Mahsûlâti" means the products of Ottoman cities in a wide geographical region. There are 383 products listed on this list. 61 products of Ottoman State were left as raw. 